\title{
EL DELITO DE OCUPACIÓN ILEGAL NO VIOLENTA DE BIENES INMUEBLES
}

\author{
Eduardo Ramón Ribas*
}

Resumen: El artículo 245.2 del Código Penal español tipifica la ocupación, sin autorización debida, de inmuebles, viviendas o edificios ajenos que no constituyan morada; también, el mantenimiento en ellos contra la voluntad de su titular. El tenor literal de dicho precepto es extremadamente amplio, pues lo son los verbos típicos, ocupar y mantener, pero también su objeto material, no solo viviendas y edificios, sino cualquier bien inmueble: terrenos, plazas de garaje o amarre, caminos, jardines, casas de aperos, etc. Especialmente problemática resulta la determinación del ámbito de aplicación de la segunda conducta típica, subsidiaria de la primera. ¿Es preciso que sea posterior a una ocupación ilícita, no necesariamente delictiva? ¿O, como sucede con el mantenimiento en morada ajena contra la voluntad de su morador, presupone también el mantenimiento en el inmueble contra la voluntad de su titular una ocupación inicial lícita, consentida por este último? Dicho de otro modo, ¿deben admitirse como propios del ámbito de aplicación del

Recibido: julio 2019. Aceptado: julio 2020

* Catedrático de Derecho Penal.

Facultad de Derecho de la Universitat de les Illes Balears. Edificio Gaspar Melchor de Jovellanos, Campus Universitario, Ctra. de Valldemossa Km 7.5, 07122 Palma de Mallorca. Email: eduardo.ramon@uib.es 
artículo 245 títulos posesorios iniciales que han dejado de legitimar la posesión?.

Palabras clave: Ocupación, Mantenimiento, Inmueble, Vivienda, Edificio, Morada.

\title{
THE CRIME OF ILLEGAL NON-VIOLENT REAL ESTATE OCCUPATION
}

\begin{abstract}
Article 245.2 of the Spanish Criminal Code typifies the occupation, without due authorization, of real estate, housing or other people's buildings that do not constitute dwelling; also, remaining at them against the will of the owner. The literal tenor of this precept is extremely broad, as are the typical verbs, occupy and remain, but also its material object, not only homes and buildings, but any real estate: land, parking spaces or mooring, roads, gardens, implements houses, etc. Especially problematic is the determination of the scope of the second typical behavior, subsidiary of the first. Does it need to be subsequent to an illegal occupation, not necessarily criminal? Or, as with the maintenance of an alien residence against the will of its inhabitant, does it also presuppose the maintenance in the property against the owner's will a legal initial occupation, consented by the latter? In other words, should they be admitted as being within the scope of Article 245 initial possession titles that have ceased to legitimize possession?.
\end{abstract}

Keywords: Occupation, Remaining, Real Estate, Property, Housing, Building, Dwelling.

\section{Introducción}

Últimamente ha destacado MAGRO SERVET que, "aunque no hay todavía estadísticas concretas sobre el grave fenómeno de la ocupación ilegal de viviendas, según publicaba, recientemente, el diario Expansión, en nuestro país hay entre 85.000 y 90.000 viviendas okupadas, de las que más de tres cuartas partes son propiedad del sector financiero. Con ello, al menos 70.000 pisos en manos de las entidades están habitados de forma ilegal. Y la mayoría de los casos se dan en Madrid y Barcelona. Por otro lado, según la memoria de la Fiscalía 
General del Estado de 2017, en 2015 se incoaron 22.917 procedimientos penales por usurpación, de los cuales solo fueron calificados 3461, mientras que el número de procedimientos penales incoados en 2016 se redujeron a 12.900 de los que tan solo fueron calificados 1.057. A su vez, en 2012 se incoaron 12.482, de los cuales fueron calificados 1508 y en 2013 12.569, y 1525 calificados"1.

Estas palabras dan evidente noticia de la problemática planteada por la usurpación de inmuebles, en relación con la cual afirma el citado MAGRO SERVET que se ve agravada "por la escasa eficacia de los sistemas procesales para obtener la expulsión urgente del ocupante ilegal de inmuebles"2.

\section{EI delito de ocupación ilegal no violenta de bienes inmue- bles: regulación y significación sistemática}

En el seno del Capítulo V (De la usurpación) del Título XIII (Delitos contra el patrimonio y contra el orden socioeconómico) del Libro II (Delitos y sus penas) del Código Penal, el artículo 245 dispone, en su segundo número, que será castigado con la pena de multa de tres a seis meses "el que ocupare, sin autorización debida, un inmueble, vivienda o edificio ajenos que no constituyeran morada, o se mantuviere en ellos contra la voluntad de su titular".

El artículo 245.2 incorpora, como puede observarse, un elemento negativo del tipo o regla de subsidiariedad expresa (ocupar un inmueble, vivienda o edificio ajenos «que no constituyan morada») en cuya virtud solo se aplicará en defecto del precepto principal, el artículo 202, que tipifica el delito de alla-

1 MAGRO SERVET, V., "Análisis de los títulos de oposición de los «okupas» ante demandas por la vía del art. 441.1 bis. $2^{\circ}$ LEC”, Diario La Ley, ${ }^{\circ}$ 9419, Sección Doctrina, 21 de Mayo de 2019.

2 MAGRO SERVET, V., "Análisis de los títulos de oposición de los «okupas» ante demandas por la vía del art. 441.1 bis. $2^{\circ}$ LEC”, ob. cit., 21 de Mayo de 2019. 
namiento de morada. Dispone este último artículo, en su primer apartado, que será castigado con la pena de prisión de seis meses a dos años "el particular que, sin habitar en ella, entrare en morada ajena o se mantuviere en la misma contra la voluntad de su morador"'.

Aunque el artículo 245.2 se refiere únicamente a bienes inmuebles, viviendas o edificios ajenos "que no constituyan morada", debe entenderse que también es precepto subsidiario respecto del artículo $203^{4}$, en el que se prevé el castigo del allanamiento del domicilio de personas jurídicas (públicas o privadas), de despacho profesional $u$ oficina y de establecimiento mercantil o local abierto al público (fuera de las horas de apertura) . $^{5}$

La diferencia punitiva entre ambas figuras es, no obstante consistir una en una ocupación (o mantenimiento ¿tras una entrada lícita o ilícita?) y la otra solo en una entrada (o mantenimiento tras una entrada consentida y, por tanto, lícita) notable: mientras el delito de ocupación ilegal del artículo 245.2 es sancionado solo con pena de multa, el delito de allanamiento de morada es castigado con pena de prisión de seis meses a dos años.

Por otra parte, y dado que el límite mínimo de pena de multa establecido por el artículo 245.2 es de tres meses, el delito de ocupación ilegal de bienes inmuebles es un delito leve, mientras el delito de allanamiento de morada es un delito menos

3 "Si el hecho se ejecutare con violencia o intimidación la pena será de prisión de uno a cuatro años y multa de seis a doce meses" (art. 202.2).

4 Ubicado, como el artículo 202, en el Capítulo II (Del allanamiento de morada, domicilio de personas jurídicas y establecimientos abiertos al público) del Título XI (Delitos contra la intimidad, el derecho a la propia imagen y la inviolabilidad del domicilio) del Libro II del Código Penal.

5 La pena prevista por el art. 203.1 es la de prisión de 6 meses a 2 años y multa de seis a diez meses. Mientras la entrada aparece penada en dicho primer apartado, el mantenimiento contra la voluntad del titular, fuera de las horas de apertura, en los referidos domicilios, despachos, oficinas o establecimientos se tipifica en el art. 203.2: el castigo previsto es una pena de multa de 1 a 3 meses. Si estas conductas se realizan con violencia o intimidación, las penas se agravan, dejando de distinguir el artículo 203.3 entre las modalidades de entrada y mantenimiento. 
grave $^{6}$. En efecto, según el artículo 33.4 letra h, es leve la pena de multa "de hasta tres meses". El artículo 13.4 dispone, por otra parte, que "cuando la pena, por su extensión, pueda considerarse como leve y como menos grave, el delito se considerará, en todo caso, como leve". Es lo que sucede en el caso que nos ocupa: aunque mínima, una fracción (concretamente un día) de la pena de multa prevista por el artículo 245.2 tiene la consideración de leve (en concreto, la multa de 3 meses), por lo que el delito debe considerarse igualmente leve. La transformación del delito de ocupación ilegal de inmuebles, antes considerado un delito menos grave, en una infracción penal de carácter leve, con importantes consecuencias teóricas y prácticas ${ }^{7}{ }^{8}$, es, según

6 Son penas menos graves, según el artículo 33.3, las penas de prisión “de tres meses hasta cinco años".

7 "Hasta al menos 16 delitos, pasan - por citar ahora solo algunas consecuencias, que después se detallan- a no ser tenidos en cuenta a efectos de reincidencia; a ver modificado su régimen de determinación y de suspensión de la pena; a tener un plazo de prescripción, tanto del delito como de la pena, de cinco años a uno; a que los plazos para la cancelación de antecedentes penales sean de seis meses, y a ser enjuiciadas conforme al procedimiento establecido para los delitos leves, entre otros importantes efectos, que sin duda tendrán importancia también en orden a la determinación de la ley penal más favorable cuando entre en vigor la LO 1/2015". Vid. GONZÁLEZ RUS, Juan José, "Secuelas «colaterales» no pretendidas de la LO 1/2015, de 30 de marzo, de reforma del Código Penal", Diario La Ley, No 8553, Sección Tribuna, 3 de Junio de 2015, Ref. D-222, Editorial LA LEY.

Vid. también, sobre las consecuencias de la desaparición de las faltas, FARALDO CABANA, Los delitos leves. Causas y consecuencias de la desaparición de las faltas, Tirant lo Blanch, Valencia 2016.

8 Aunque un sector doctrinal estima que sí es posible proceder a la detención por delitos leves con carácter general, a mi juicio, la respuesta no admite duda: no lo es. Opinan en aquel sentido, por ejemplo, HERNÁNDEZ GARCÍA/RAMÍREZ ORTIZ, "Las consecuencias procesales de la reforma", en Comentario a la reforma penal de 2015, dir. Gonzalo Quintero Olivares, Thomson Reuters Aranzadi, Cizur Menor, 2015, pág. 255; DE LA MATA BARRANCO, "Detención policial por comisión de delitos leves", en $\mathrm{Al}$ macén de Derecho, Julio 27, 2015, http://almacendederecho.org/detencionpolicial-por-comision-de-delitos-leves/.

Afirman igualmente que no es posible la detención por delitos leves, muy fundadamente, IZQUIERDO TÉLLEZ, "Se puede detener por delito leve", 
GONZÁLEZ RUS, una "secuela colateral, no pretendida", de la LO 1/2015, de 30 de marzo. La elevación por parte de esta "del límite de duración que determina la calificación de la multa como pena leve o como pena menos grave, ha supuesto que, a partir de su entrada en vigor, al menos 16 figuras delictivas deban ser consideradas como delitos leves, y no como delitos menos graves, que es la calificación que hasta la LO 1/2015 han tenido siempre, y que tengo la certidumbre de que el legislador no ha sido consciente de que también modificaba (como secuela colateral, no pretendida)" 9 .

La Fiscalía General del Estado considera preocupante "la degradación de las usurpaciones a delito leve, que ha permitido en numerosas ocasiones dar una respuesta más ágil y rápida a una conducta demasiado generalizada y grave, pero no permite graduar conductas y dicha consideración hace que las conductas más graves, con una mayor permanencia temporal y, en consecuencia, con un mayor perjuicio para los perjudicados, no tengan una respuesta penal adecuada y justa"10.

También establece una regla de subsidiariedad expresa el artículo 37, numeral séptimo, de la Ley Orgánica 4/2015, de 30 de marzo, de protección de la seguridad ciudadana. Dicho precepto tipifica como infracción leve ${ }^{11}$ "la ocupación de cualquier

en Diario La Ley, núm. 8582, Sección Tribuna, 14 de julio de 2015; FARALDO CABANA, Los delitos leves. Causas y consecuencias de la desaparición de las faltas, Tirant lo Blanch, Valencia 2016, pág. 200.

9 "Creo posible afirmar que esta reforma no estaba dentro de los propósitos del legislador, que no ha sido consciente en ningún momento del proceso legislativo de que esta modificación se producía automáticamente, como efecto de las que introducía de forma deliberada". Vid. GONZÁLEZ RUS, Juan José, "Secuelas «colaterales» no pretendidas de la LO 1/2015, de 30 de marzo, de reforma del Código Penal", ob. cit., 3 de Junio de 2015.

10 Memoria Elevada al Gobierno de S.M. Presentada al Inicio del Año Judicial por la Fiscal General del Estado Excma. Sra. D. ${ }^{a}$ Consuelo Madrigal Martínez Pereda. Madrid, 2016. pág. 801.

https://www.fiscal.es/memorias/memoria2016/FISCALIA_SITE/recursos/ pdf/MEMFIS16.pdf

11 Sancionable, en virtud del artículo 39 de la propia LO 4/2015, con multa de 100 a 600 euros. 
inmueble, vivienda o edificio ajenos, o la permanencia en ellos, en ambos casos contra la voluntad de su propietario, arrendatario o titular de otro derecho sobre el mismo, cuando no sean constitutivas de infracción penal" 12 .

Dado que el artículo 245.2 es subsidiario respecto del artículo 202, ambos del Código Penal, el artículo 37 de la LO 4/2015 contiene una doble regla de subsidiariedad: solo se aplicará cuando la ocupación del inmueble, vivienda o edificios ajenos, o la permanencia en ellos, no sean constitutivos de delito de allanamiento de morada ni del delito de ocupación ilegal no violenta tipificado como una infracción de carácter patrimonial.

El artículo 245.2 limita por arriba, por tanto, con el artículo 202 (y 203) y por abajo con el artículo 37 de la LO 4/2005. Si la ocupación tuviere lugar de forma violenta o intimidatoria, se aplicaría el artículo 245.1, según el cual, "al que con violencia o intimidación en las personas ocupare una cosa inmueble o usurpare un derecho real inmobiliario de pertenencia ajena, se le impondrá, además de las penas en que incurriere por las violencias ejercidas, la pena de prisión de uno a dos años, que se fijará teniendo en cuenta la utilidad obtenida y el daño

12 "Esta infracción sanciona a aquellos (ej.- movimiento social «okupa») que contra la voluntad de su propietario o similar, invaden, acceden o se mantienen en un edificio, vivienda o inmueble, siempre y cuando no constituya morada, en cuyo caso nos encontrariamos en la esfera del delito del allanamiento art. 202 CP. El problema es que esta infracción se encuentra intimamente relacionada con el delito de usurpación del art. 245.2 CP que tipifica prácticamente lo mismo, de manera que habrá que decidir en cada situación concreta que vía se ha de seguir. En el mismo orden de cosas, esta infracción introduce como novedad en su párrafo $2 .^{\circ}$ la mención expresa a la ocupación de la vía pública, con infracción de lo dispuesto por la Ley o contra la decisión adoptada en aplicación de aquella por la autoridad competente, dentro de la cual se encuentra la venta ambulante no autorizada, dando la posibilidad de sancionar la ocupación de la vía pública con tenderetes, pérgolas, tiendas de campaña, construcciones portátiles o desmontables u objetos análogos que dieron lugar a las conocidas acampadas multitudinarias (Puerta del Sol de Madrid). Vid. GUILLÉN ÁlVAREZ, I., "Estudio y análisis jurídico de la nueva Ley Orgánica 4/2015, de protección de la seguridad ciudadana", Diario La Ley, № 8633, Sección Doctrina, 27 de Octubre de 2015, Ref. D-396, Editorial LA LEY. 
causado". Aunque este precepto no hace alusión expresa al hecho de que la cosa inmueble ocupada no sea morada, debe no serlo, pues si lo fuere devendría aplicable el delito de allanamiento (violento o intimidatorio) de morada.

Una concepción sumamente particular es la defendida por BAUCELLS LLADÓS. A su juicio, la exigencia de que concurra violencia o intimidación en las personas es un elemento típico común a los dos números del artículo 245. Observa, por supuesto, que "el hecho de que en el párrafo primero del art. 245 apareciera la expresión "con violencia o intimidación en las personas» y que esta no apareciera a la vez en el segundo, ha llevado a la totalidad de la doctrina y a un sector ${ }^{13}$ de la Jurisprudencia a entender que mientas en el párrafo primero se tipifica la ocupación violenta o usurpación propia, en el párrafo segundo se tipificaba la ocupación pacífica o usurpación impropia"14.

"Sin embargo", explica, "en primer lugar, parece precipitado afirmar que esa fuera la voluntad del legislador, porque en más de 3000 páginas de la discusión parlamentaria no aparece ni una sola interpretación en ese sentido. Pero precipitado también desde cualquiera de los otros criterios de interpretación legal". Alega este autor tanto razones históricas ("la usurpación pacifica solo fue reprimida penalmente en el Código totalitario de 1928 o en épocas, como la del Código Penal de 1848, donde los inmuebles no gozaban todavía de protección registral" ${ }^{15}$ ) como gramaticales ("el art. 245.2 no exige expresamente que la conducta necesite desarrollarse "sin violencia ni intimidación», expresión que sí fue utilizada por el legislador en aquellos códigos históricos en los que ha querido criminalizarla expresamente. Por ello, parece que donde el legislador no ha exigido expresamente la ausencia de violación no pueda exigirla el intérprete salvo violando el principio de prohibición de analogía" ${ }^{16}$, o de

13 ¿Solo a un sector?

14 Vid. BAUCELlS LladÓs, "Comentario al art. 245 del Código Penal", en Comentarios al Código Penal. Parte Especial. Tomo I, directores Juan Córdoba Roda y Mercedes García Arán, Marcial Pons, Madrid 2004, pág. 725.

15 "En consecuencia, no parece que deba presumirse esa voluntad en el legislador penal democrático de 1995". Vid. BAUCELLS LLADÓS, "Comentario al art. 245 del Código Penal", ob. ult. cit., pág. 725.

16 Vid. BAUCELLS LLADÓS, "Comentario al art. 245 del Código Penal", ob. ult. cit., págs. 725 y 726 . 
falta de atención a la realidad social del tiempo en que debe ser aplicada la norma ("entender que el art. 245.2 se aplica siempre que el autor ocupa o se mantiene sin violencia o intimidación supondría otorgar relevancia penal a numerosas situaciones que previamente han sido contractuales pero que, posteriormente, han podido dejar de serlo: precaristas que están en una simple situación de hecho por habérseles resuelto o finalizado el contrato; arrendatarios; usufructuarios, etc.") ${ }^{17}$; también alega, por último, que "esta concepción llevaría los bienes a la contradicción de calificar como delictivas conductas que en otras ramas del ordenamiento jurídico, como el Derecho civil, son consideradas como legitimas formas de adquirir la propiedad: En efecto, el Derecho civil reconoce efectos jurídicos a la ocupación pacifica incluso cuando se desarrolla sin justo título $y$ de mala fe" $" 18$.

La tesis de BAUCELLS LLADÓS está guiada, obviamente, por su deseo de restringir al máximo el ámbito de aplicación del art. 245.2, de eliminarlo de facto de nuestro ordenamiento. Aunque no la comparto, es loable, sin duda, el esfuerzo por fundamentarla. Eso sí, afirmar que quien sostiene que no es precisa la utilización de violencia o intimidación para entender realizado el tipo descrito en el artículo 245.2 del Código Penal ${ }^{19}$ incurre

17 "También permitiría considerar como delictivas las conductas del que acampare de forma permanente en un terreno ajeno o del pastor que dejare a su rebaño pastar en finca ajena de forma permanente. Todas estas conductas, sin ser plenamente lícitas (¡!!), merecen -en la realidad social en que deben ser aplicadas-que a lo sumo posibiliten el ejercicio de acciones civiles orientadas a establecer el pacifico disfrute de los bienes y derechos patrimoniales". Vid. BAUCELLS LLADÓS, "Comentario al art. 245 del Código Penal", ob. ult. cit., pág. 726.

18 "Le llega a dotar de consecuencias tan importantes como la defensa interdictal y la prescripción adquisitiva. Además, el conflicto entre los intereses del ocupante y del legítimo titular aparece detalladamente regulado en los interdictos de recuperar la posesión. Con todo ello, considerar típicas las conductas de ocupación pacifica también sería contradictorio con los principios de fragmentariedad y del ultima ratio del Derecho Penal". Vid. BAUCELLS LLADÓS, "Comentario al art. 245 del Código Penal”, ob. ult. cit., pág. 726.

19 No solo no lo es, sino que, si se emplearen una u otra el tipo devendría inaplicable, pues debería aplicarse el artículo 245.1. 
en una prohibida analogía es forzar la naturaleza de las cosas: el tipo no solo no la exige, sino que la excluye si es puesta en contacto con el tipo descrito en el artículo 245.1. Quisiera destacar también la debilidad del argumento en último lugar citado: el artículo 1955 del Código Civil dispone que el dominio de los bienes muebles se prescribe por la posesión no interrumpida de tres años con buena fe y que "también se prescribe el dominio de las cosas muebles por la posesión no interrumpida de seis años, sin necesidad de ninguna otra condición". Advierte al respecto el artículo 1956 del mismo cuerpo legal que las cosas muebles hurtadas o robadas no podrán ser prescritas por los que las hurtaron o robaron, ni por los cómplices o encubridores, " $a$ no haber prescrito el delito o falta, o su pena, y la acción para exigir la responsabilidad civil, nacida del delito o falta". Dicho de otro modo, también las cosas muebles hurtadas o robadas pueden ser adquiridas por prescripción (y su posesión goza de protección jurídica) transcurrido determinado plazo ${ }^{20}$, lo cual no impide afirmar la existencia de un delito de hurto o robo.

Según QUINTERO OLIVARES, la característica determinante de este último delito es precisamente el uso de la violencia en su doble forma de violencia física y violencia intimidatoria. "Pero esa violencia", sigue diciendo dicho autor, "en el delito de usurpación tiene un carácter determinante, ya que su ausencia no se corresponde, en cuanto a efectos, con una relación como la que media entre robo y hurto, sino que puede, en muchos casos, determinar la atipicidad: por ejemplo, realizar acampada en un terreno particular, o pasar por un terreno ajeno, son conductas que, sin ser plenamente lícitas, no tienen carácter delictivo, sino que a lo sumo posibilitan el ejercicio de acciones civiles orientadas a restablecer la integridad o el pacifico disfrute de los derechos patrimoniales, que en el delito de usurpación se turban con el empleo de la violencia"21.

20 Los delitos leves, por ejemplo, el hurto de cosa mueble de valor no superior a 400 euros, prescriben al año.

21 Vid. QUINTERO OLIVARES, "Comentario al artículo 245 del Código Penal”, en Comentarios al Código Penal español. Tomo I (Artículos 1 a 233), $7^{\text {a }}$ edición, Aranzadi, Pamplona 2016, ebook. 
No resulta exacta, a mi juicio, dicha afirmación: si tomamos como punto de partida, como hace el propio QUINTERO OLIVARES, que "la mención separada a cosas inmuebles $y$ derechos reales es un tanto superflua, pues todos los derechos reales se ejercitan sobre cosas inmuebles, y lo que se usurpa es el ejercicio del derecho, no la cosa", la atipicidad del segundo comportamiento citado (pasar por un terreno ajeno) no trae causa del no empleo violencia o intimidación sino de la inexistencia, propiamente, de una ocupación o usurpación. La atipicidad de la primera conducta referida por aquel autor (realizar una acampada en un terreno particular) tampoco dependerá de la utilización, o no, de violencia o intimidación, sino del hecho, una vez más, de que se considere que existió, o no, una oсираción o usurpación del bien inmueble. Si no la hubiere, la conducta será atípica; si la hubiere, y se considera que ese es un bien inmueble susceptible de la protección ofrecida por el artículo 245.2 del Código Penal, la conducta será típica pese a que no se hubiere empleado violencia o intimidación.

Es preciso tener presente en todo momento que también el artículo 245.1 exige, además del empleo de violencia o intimidación en las personas, que se ocupe una cosa inmueble ajena o se usurpe un derecho real inmobiliario igualmente ajeno ("de pertenencia ajena"). La primera de estas conductas es, indiscutiblemente, la misma que la tipificada en el artículo $245.2^{22}$ : la

22 El artículo 245.1 no distingue entre ocupación y mantenimiento, sino entre ocupación de inmuebles y usurpación de derechos reales inmobiliarios. ¿Deben considerarse típicas las conductas de mantenimiento? Esta segunda modalidad típica del artículo 245.2 posee, como veremos, un ámbito de aplicación propio, distinto de la ocupación inicial ilícita, por lo que su inclusión en el primer número del artículo 245 no resulta indiscutible. A juicio de BAUCELLS LLADÓS ("Comentario al art. 245 del Código Penal", ob. cit., pág. 717), "respecto de la acción mantenerse debemos afirmar que esta también está incluida en el párrafo primero porque, aunque no aparezca expresamente recogida, se desprende de la propia dinámica de la acción ocupar". Esta es también, pese a la diferenciación incorporada por el artículo 245.2, mi opinión. Quien ocupa de forma inicial un inmueble utilizando violencia o intimidación realiza el tipo penal descrito en el art. 245.1. Tam- 
única diferencia entre una y otra es, por tanto, que en este segundo caso no se emplea violencia o intimidación. El artículo 245.1 es, desde esta perspectiva, un tipo agravado del artículo $245.2^{23}$. Quizá la segunda conducta descrita por el artículo 245.1 sí añada algún supuesto al anterior ${ }^{24}$, pero si se acepta que la usurpación del derecho real inmobiliario en realidad recae inmediatamente sobre un bien inmueble y solo indirectamente sobre el derecho real, la mención separada de ambas conductas resultaría, como observa QUINTERO OLIVARES, superflua.

Dicho todo ello, es obligado destacar que mediante las conductas tipificadas en el artículo 245 el legislador tutela, a diferencia, por ejemplo, de los delitos de hurto (art. 234.1: el que, con ánimo de lucro, tomare las cosas muebles ajenas sin la voluntad de su dueño) y robo (art. 237: los que, con ánimo de lucro, se apoderaren de las cosas muebles ajenas empleando fuerza en las cosas para acceder o abandonar el lugar donde éstas se encuentran o violencia o intimidación en las personas, sea al cometer el delito, para proteger la huida, o sobre los que acudiesen en auxilio de la víctima o que le persiguieren), bienes inmuebles. Los delitos de usurpación u ocupación son, por con-

bién quien, ocupando lícitamente de forma inicial el inmueble, ve como se extingue su derecho y sigue ocupándolo con violencia o intimidación en las personas.

23 También cabe sostener que el art. 245.2 es un tipo privilegiado del art. 245.1. Desde esta perspectiva, la ausencia de violencia o intimidación podría considerarse un elemento negativo del tipo. Desde nuestra perspectiva, el tipo básico es el previsto y penado en el artículo 245.2, de modo que la utilización de violencia o intimidación determinan una agravación del comportamiento típico.

24 Según el Diccionario de la Real Academia, usurpar significa "apoderarse de una propiedad o de un derecho que legítimamente pertenece a otro, por lo general con violencia". Distinguía con toda nitidez entre ocupar y usurpar HUERTA TOCILDO, a cuyo juicio ocupar implica una mera perturbación en el uso o disfrute del bien inmueble, sin ánimo de apropiación, de poseer la cosa como propia, mientras usurpar lleva consigo la atribución de la titularidad de un derecho real sobre un inmueble, la subrogación en dicha titularidad. Vid. HUERTA TOCILDO, Susana, Protección penal del patrimonio inmobiliario, Ed. Civitas, $1^{a}$ edición. Madrid, 1980, págs. 80 y ss. 
siguiente, como afirman QUINTERO OLIVARES ${ }^{25}$ o VIVES ANTÓN/GONZÁLEZ CUSSAC ${ }^{26}$, delitos contra el patrimonio. Su inclusión en el Capítulo V del Título XIII del Libro II del Código Penal, es decir, entre los delitos patrimoniales y contra el orden socioeconómico, da correcta noticia, por tanto, de su objeto de tutela.

Según BAUCELLS LLADÓS, el bien jurídico protegido es "el tranquilo disfrute de los bienes inmuebles, entendido éste como ausencia de perturbación en el ejercicio de la posesión o de cualquier derecho real sobre los mismos"; exige, además, que los bienes y derechos sean valorables económicamente y protegidos no solo por el ordenamiento jurídico-civil, sino también por el constitucional. A su juicio, con evidente intención de restringir el ámbito de aplicación del tipo penal, será dicha concepción constitucional la que, desde la función interpretativa que se le viene otorgando al bien jurídico, "deberá orientar la interpretación de estos tipos penales"27.

Resulta interesante, a este respecto, referirse a una resolución judicial que constituye, sin duda, una referencia en la materia: la Sentencia núm. 800/2014, de 12 de noviembre, del Tribunal Supremo, que considera constitutiva de delito la ocupación de una finca rústica militar, con finalidad inicial de protesta social, "pero superando su naturaleza de acto simbólico", durante dieciocho días. En su Fundamento de Derecho Tercero

25 Vid. QUINTERO OLIVARES, "Comentario al artículo 245 del Código Penal", ob. cit., ebook.

26 "El delito de usurpación ha de estimarse puramente patrimonial. La violencia o la intimidación determinan la relevancia típica del hecho (siquiera, es preciso añadir, a los efectos del artículo 245.1), pero no forman parte del contenido de injusto del mismo. La usurpación aparecerá, pues, necesariamente, en el seno de un concurso real de delitos, con las coacciones, lesiones, etc. y, en ningún caso, ni siquiera en el de las coacciones o amenazas, cabrá articular un concurso de leyes". Vid. VIVES ANTÓN/GONZÁLEZ CUSSAC, "Comentario al art. 245 del Código Penal", en Comentarios al Código Penal de 1995. Vol. I, Valencia 1996, Tirant lo blanch, documento TOL186.649.

27 Vid. BAUCELLS LLADÓS, “Comentario al art. 245 del Código Penal”, ob. cit., pág. 713. 
dice así el Alto Tribunal: "Los delitos de usurpación, tipificados en el Capítulo V del Título XIII del Código Penal de 1995, constituyen una modalidad de delitos patrimoniales que tutelan especificamente los derechos reales sobre bienes inmuebles. En ellos el bien jurídico protegido es el patrimonio inmobiliario, $y$ como delitos patrimoniales la lesión del bien jurídico requiere que se ocasione un perjuicio al titular del patrimonio afectado, que es el sujeto pasivo del delito".

En la previsión de sus penas incide significativamente, como explica igualmente QUINTERO OLIVARES, la existencia de una tutela registral de los bienes inmuebles: la previsión de castigos notablemente más benignos (multa, salvo si se emplea violencia o intimidación, en cuyo caso la pena será de prisión) que los impuestos en otros delitos del mismo Título XIII del Libro II del Código Penal halla su razón "en un presupuesto teórico comprensible: que los bienes inmuebles pueden gozar de una permanente protección registral de la que carecen los bienes muebles y eso hace que la tutela penal descanse sobre el presupuesto de que no es posible un daño irreversible de pérdida dada la naturaleza del objeto y su situación jurídica"28.

\section{3. «Ocupar» (sin autorización debida) y «mantenerse» (con- tra la voluntad): las modalidades de conducta típica}

El artículo 245.2 distingue dos modalidades de conducta típica:

- ocupar, sin autorización debida, un inmueble, vivienda o edificio ajenos que no constituyan morada

- mantenerse en un inmueble, vivienda o edificio ajenos contra la voluntad de su titular.

28 "Ciertamente se puede oponer que ese razonamiento fracasa cuando el dato registral es incorrecto o inexistente, pero también es comprensible que el Derecho penal positivo no se construya en esta materia dando realidad o normalidad a la inoperancia eventual del registro inmobiliario". Vid. QUINTERO OLIVARES, "Comentario al artículo 245 del Código Penal", ob. cit., ebook. 
Dado que ambas conductas recaen sobre el mismo objeto material, es decir, sobre un inmueble, vivienda o edificio ajenos, resulta manifiesta la voluntad de la ley de distinguir dos comportamientos típicos; hecha la distinción por la ley, también el intérprete deberá diferenciar, concediendo a una y otra conducta típicas un ámbito de aplicación propio.

Es preciso avanzar ya que el tenor literal de la ley es realmente amplio y no solo, por cierto, como consecuencia de esta última distinción.

\section{1. ¿Qué significa «ocupar»?}

El artículo 245.2 prevé el castigo, como hemos visto, en primer término, de quien ocupare, sin autorización debida, un inmueble, vivienda o edificio ajenos que no constituyan morada.

La exigencia que incorpora el citado verbo típico es superior, sin duda, a la propia del delito de allanamiento de morada: mientras este solo requiere, en su modalidad más conocida, que el sujeto activo entre en la morada ajena, el delito objeto de análisis requiere que el bien inmueble, vivienda o edificio ajenos sean ocupados. Se requiere, por supuesto, una entrada, pero no es suficiente con ello: el sujeto activo, de acuerdo con el significado atribuido por el Diccionario de la Real Academia al verbo ocupar, debe tomar posesión del inmueble, invadirlo o instalarse en él. Es precisa, por tanto, una mínima, aunque indefinida, permanencia. $\mathrm{O}$, más exactamente, una vocación de una mínima permanencia, pues el delito deberá entenderse consumado de forma instantánea cuando su protagonista se instale en el bien inmueble con dicha vocación, aunque no llegue a alcanzar esa mínima e indefinida permanencia en él.

Obviamente, una vivienda es ocupada si una persona se instala en ella y la habita ${ }^{29}$ durante años; también, con certeza, si la habita durante meses o, incluso, semanas. ¿Y si solo la habita durante unos días?

29 Este es otro de los significados del verbo ocupar según el referido Diccionario de la Real Academia: habitar una casa. 
La mencionada indefinición se advierte ahora fácilmente: ¿ocupa un inmueble quien permanece en él solo unas horas y no tenía vocación de ocuparla más tiempo? ¿Es preciso un transcurso mínimo de horas, quizá veinticuatro, o es necesaria una permanencia mínima de días, por ejemplo, una semana?

Se ha sostenido que la ocupación no conlleva la estabilidad que precisa el tipo en supuestos de permanencia en el inmueble durante dos días, tres días, cuatro días, una semana, quince días, un mes e, incluso, dos meses ${ }^{30}$. En sentido contrario, otras veces se ha considerado que sí colma las exigencias del tipo una estancia de un mes, una semana, unos días o incluso una noche $^{31} 32$.

Es obligado subrayar, al respecto, la adelantada caracterización de este delito (tanto doctrinal como jurisprudencialmente) como una infracción de consumación instantánea: se perfecciona desde el mismo momento en que el sujeto activo se instala en el inmueble. La ausencia de una cierta duración de la estancia se suple, por tanto, con un elemento subjetivo: la vocación de permanencia del ocupante. Subsiste, sin embargo, la

30 Vid. Sentencia núm. 381/2005, de 10 de noviembre (Sección 4a ), de la Audiencia Provincial de Valladolid: "lo acreditado en autos es que la ocupación no conlleva la estabilidad que precisa el tipo, la gente entraba y salía, día y noche, del inmueble, sin ocupar con carácter de permanencia el mismo. Así, Emilio, llevaba 15 dias únicamente en la vivienda, cuando se le requirió para declarar en estos autos, Rodrigo unos dos meses, como Irene, y como Nuria". Cierto es, eso sí, que en el cado enjuiciado por dicha sentencia concurren otras circunstancias (necesidad, inhabitabilidad del inmueble) que ayudan a limitar la elasticidad del tipo.

31 Vid. Sentencia núm. 394/2000, de 1 de septiembre (Sección 2a), de la Audiencia Provincial de Alicante: "Es evidente que tal conducta integra el delito previsto en el art, 245.2 del Código Penal, pues la usurpación de inmuebles requiere una mínima permanencia temporal en la ocupación, circunstancia que concurre en el supuesto de autos ya que el acusado paso la noche en la vivienda hasta que fue desalojado nuevamente por la Guardia Civil".

32 Vid., citando abundante jurisprudencia, JIMÉNEZ PARÍS, José Miguel, Usurpación pacifica de bienes inmuebles, https://eprints.ucm.es/43556/1/ T39000.pdf, Tesis doctoral, Universidad Complutense de Madrid, 2017, págs. 605 y 606. 
necesidad de determinar el alcance de dicha vocación: ¿cuánto tiempo debe tener intención de permanecer en el inmueble el sujeto activo?

La cuestión temporal quizá no sea, pese a todo, la única decisoria. Si bien parece claro que deben excluirse usos meramente esporádicos u ocasionales, sin vocación de la permanencia mínima que se estime exigible y, por tanto, de escasa entidad o significación, cabe preguntarse si se requiere una determinada clase de ocupación: ¿debe el bien inmueble ser ocupado, por ejemplo, en concepto de vivienda? ¿Es suficiente instalarse en él para realizar actividades de otra naturaleza? ¿Puede el inmueble ser ocupado por una persona sin que esta esté jamás en él? ¿Debe excluir la ocupación el uso del inmueble por quien sea el titular de dicho uso?

Planteando algunos ejemplos será más sencillo observar la problemática planteada.

- Un grupo de personas invaden una vivienda que lleva largo tiempo inhabitada y en evidente situación de abandono. No la utilizan, sin embargo, en concepto de vivienda, sino de lugar de reunión o como sala de fiestas.

- Una empresa constructora utiliza, sin autorización de su titular, un terreno en el que instala abundante maquinaria y en el cual permanecen aparcados numerosos vehículos por las noches y fines de semana.

- Una familia se instala con su caravana en un terreno rústico, lo cual no impide que este último sea utilizado por sus titulares, por ejemplo, para seguir cultivándolo o para pasear por él.

Es preciso advertir que en este momento solo nos interrogamos acerca del significado del verbo nuclear del tipo, ocupar; cuestión distinta es si los bienes inmuebles susceptibles de ocupación típica deben ser, o no, como no resulta extraño opinar, viviendas o construcciones.

Dicho ello, y dejando al margen esta última cuestión, debe quedar claro que son susceptibles de ocupación, en sentido 
literal, tanto viviendas como construcciones, pero también bienes inmuebles distintos de unas y otras. El verbo ocupar, dicho de otra forma, no incorpora, por sí mismo, otro límite que no sea la exclusión de conductas que literalmente no merezcan su adjetivación como ocupación.

En los tres supuestos referidos no es difícil concluir, por tanto, que se ha producido una ocupación, lo cual no significa, aún, que sea típica: deben todavía analizarse los demás elementos típicos y, por supuesto, determinar cuál es el bien jurídico protegido y, en consecuencia, el ámbito de aplicación, externamente delimitado por su interpretación literal, del tipo penal.

Otros ejemplos en los que se advierte, literalmente, una ocupación de bienes inmuebles son los siguientes: usar una piscina ajena a diario en los meses de verano con despojo simultáneo de los titulares de su uso; realizar obras en una parcela ajena o instalar en ella maquinaria; colocar vallas de publicidad en un terreno o edificio ajenos; utilizar una plaza de garaje o de amarre con exclusión de su uso por parte de sus titulares; explotar agrícolamente terrenos ajenos o utilizarlos para realizar vertidos o enterrar desechos de animales ajenos.

Considerar que todos estos supuestos son constitutivos de un delito de ocupación ilegal en los términos descritos por el artículo 245.2 no depende solo, es preciso insistir en ello, de su adjetivación como ocupaciones de bienes inmuebles, sino de otras consideraciones propias de la tipicidad, pero debe destacarse ya que sí son, efectivamente, ocupaciones de bienes inmuebles.

En definitiva, el término ocupar, sumamente amplio, traza un marco muy generoso dentro del cual, lógicamente, deberá operar la interpretación judicial. Dado que se exige tomar posesión del inmueble, invadirlo o instalarse en él, no serán ocupaciones las simples entradas o usos esporádicos u ocasionales. Se ocupa, por otra parte, desde que se produce la toma de posesión, invasión o instalación, consumándose de forma instantánea, por consiguiente, el delito. No es necesaria, dicho de otra forma, 
una permanencia posterior de la ocupación; si se produce, dicha permanencia extenderá el momento consumativo: el delito, por tanto, se seguirá cometiendo mientras se continúe ocupando. Expresado de otro modo: la permanencia de la ocupación no pertenece a la fase de agotamiento del delito sino a su ejecución; el delito, desde esta perspectiva, seguirá siendo actual transcurridos varios meses si no se interrumpió la ocupación. El ocupador u ocupadores no solo cometieron un delito al ocupar el inmueble; lo siguen cometiendo mientras permanecen en él, pues, como exige el tipo, siguen ocupándolo.

Para que efectivamente se ocupe el inmueble de forma instantánea, será precisa, eso sí, como decía, una mínima vocación de permanencia: solo entonces cabrá afirmar que se toma posesión del bien inmueble, que es invadido por los ocupadores o que estos se instalan en él. A aquella se refiere el Tribunal Supremo en su, ya citada, Sentencia núm. 800/2014, de 12 de noviembre: el primer elemento del delito es, dice, "la ocupación, sin violencia o intimidación, de un inmueble, vivienda o edificio que en ese momento no constituya morada de alguna persona, realizada con cierta vocación de permanencia”.

\section{2. ¿Qué significa «mantenerse»?}

Aunque existe un evidente paralelismo entre el artículo 245.2 y el artículo 202, que tipifica la conducta del particular que, sin habitar en ella, entrara en morada ajena o se mantuviere en la misma contra la voluntad de su morador, la interpretación de este segundo comportamiento en el ámbito del artículo 245.2 (o se mantuviere en ellos -en los bienes inmuebles- contra la voluntad de su titular) quizá no guarde con la primera conducta análoga relación.

En el delito de allanamiento de morada dicha segunda conducta presupone que el sujeto activo entró en la morada ajena con consentimiento del morador y que una vez este exige que aquel la abandone, el sujeto activo permanece o se mantiene en la morada pese a la voluntad contraria del morador. La segunda 
modalidad, introducida en el Código Penal en 1952 es, en realidad, subsidiaria de la primera ${ }^{33}$; su fin es ofrecer una tutela completa a la morada, cuya inviolabilidad reconoce como derecho fundamental la Constitución.

¿Presupone también el mantenimiento en el inmueble contra la voluntad de su titular una ocupación inicial lícita, consentida por este último?

Con independencia de cuál sea la respuesta a esta pregunta, es preciso dar sentido a dicha segunda conducta, subsidiaria de la primera como lo es la análoga prevista en el citado artículo 202. No debe olvidarse que ocupar el inmueble sin autorización debida es una conducta, según hemos adelantado, de instantánea consumación, sí, pero que normalmente permanecerá en el tiempo. En tal caso tendrá lugar un mantenimiento que no merecerá su independiente consideración, pues es, en realidad, la misma ocupación a la que dio inicio el sujeto activo.

No resulta sencillo hallar una respuesta exenta de objeciones. Literalmente son admisibles, como constitutivas de esta modalidad de mantenimiento contra la voluntad del titular del inmueble, conductas de permanencia en este último tras ocupaciones lícitas iniciales que han dejado de legitimar la posesión. Si

33 Vid, por ejemplo, MORALES PRATS, "Comentario al art. 202 del Código Penal”, en Comentarios al Código Penal español. Tomo I (Artículos 1 a 233), $7^{\text {a }}$ edición, Aranzadi, Pamplona 2016, ebook: "Por lo que respecta a la relación a establecer entre las dos modalidades típicas debe remarcarse que la estructurada de forma omisiva (permanecer en morada ajena contra la voluntad del morador) es subsidiaria de la modalidad principal, cifrada en la entrada en morada ajena sin la anuencia del morador". En el mismo sentido, REBOLLO VARGAS, "Comentario al art. 202 del Código Penal”, en Comentarios al Código Penal. Parte Especial. Tomo I, directores Juan Córdoba Roda y Mercedes García Arán, Marcial Pons, Madrid 2004, pág. 490: "el «mantenerse» en la morada sin consentimiento constituye una conducta omisiva que supone, inicialmente, un consentimiento inicial del morador que en primera instancia autoriza la entrada en la misma, aunque, posteriormente, exige a quien ha accedido a ella (con su consentimiento) que se ausente de la misma. Se trata de una conducta subsidiaria de la anterior que excluye la imputación por el acceso y que imposibilita un concurso entre ambas modalidades típicas". 
el mantenimiento típico exigiera que fuera precisamente esta la situación, el paralelismo con el artículo 202 se acentuaría. De hecho, una primera y superficial aproximación al tipo parece aconsejar una interpretación que establezca dicho paralelismo. El problema es que tendrían cabida en el tipo penal conductas de mantenimiento en el inmueble una vez finalizado, por ejemplo, el contrato de arrendamiento o después de la revocación del consentimiento que autorizaba una situación de precario, comportamientos, ambos, cuya pertenencia al Derecho Civil nadie ha cuestionado.

¿Deben admitirse como propios del ámbito de aplicación del artículo 245 títulos posesorios iniciales que han dejado de legitimar la posesión? En los supuestos en que el referido título posesorio es un contrato de arrendamiento que llegó al final de su plazo la intervención penal parece inimaginable. ¿Sucede otro tanto si el título posesorio es un precario? ${ }^{34}$

Lo que no ofrece dudas, según defiende la Sentencia de la Audiencia Provincial de Ciudad Real 72/2003, de 21 de abril, es que la referencia no sólo a la ocupación sino al mantenimiento parece tener por finalidad evitar la impunidad de conductas estructuralmente semejantes cuando el detentador ilegítimo ha adquirido la posesión inmediata y de hecho sin que conste si existe o no autorización, por el propio desconocimiento del titular de ese derecho, o cuando haya habido una situación de tolerancia, posesión ésta que se torna delictiva a partir de la expresa voluntad contraria del titular, pues en tal caso, y a partir de ese momento, en realidad, se produce una verdadera ocupación tan ilegal como la que desde un principio se inicia sin permiso del que tiene la facultad de disfrute del bien. La posesión, como tal, se convierte así en un parámetro plausible de diferenciación conceptual que se ha de relacionar inevitablemente con los requisitos objetivos y subjetivos del tipo y las circunstancias del caso.

34 En 2004 BAUCELLS LLADÓS ("Comentario al art. 245 del Código Penal”, ob. cit., pág. 726, nota 163) decía que no había visto ninguna sentencia penal "en la que se condene a sujetos que se encuentren en precario", lo cual, por otra parte, le parecería excesivo. Tampoco a mí me consta la existencia de condena alguna condenatoria por mantenerse en el inmueble, en el que se estaba en precario, una vez expresa el titular su voluntad contraria. 
Una segunda opción interpretativa consiste en exigir que el mantenimiento en el inmueble contra la voluntad de su titular esté vinculado a una ocupación inicial ilegal ${ }^{35}$, si bien será preciso hallar un ámbito de aplicación propio para dicha conducta, diferenciándola, como he adelantado, de la simple permanencia tras una ocupación delictiva.

Dicho ámbito propio de aplicación no existirá si se exige una ocupación ilícita inicial, con ausencia, por tanto, de un título posesorio legitimador de la posesión, y la plena conciencia de dicha ilícita ocupación o ausencia de título legitimador. En efecto, si el sujeto activo ocupó la vivienda sin autorización debida y tenía conocimiento de ello, es decir, actuó dolosamente, se habrá realizado la conducta típica descrita en primer lugar por el artículo 245.2; y el mantenimiento subsiguiente, como he explicado, no es una conducta independiente, sino esa misma inicial ocupación ilícita, su simple continuidad o permanencia y extensión natural de la consumación del tipo, que seguirá cometiéndose en tanto perdure la ocupación o mantenimiento, términos, ahora, equivalentes.

Parece que nos hallamos ante un camino sin salida: la letra del tipo penal se limita a tipificar el mantenimiento en el inmueble contra la voluntad de su titular, consintiendo, y aconsejando, en principio, su desconexión de una ocupación ilícita inicial, lo cual nos conduce a una realmente insatisfactoria solución por invasión de un espacio tradicionalmente reservado ( $\sin$ excepción) al Derecho Civil; la ocupación de este ámbito ajeno dejaría sin sentido los instrumentos civiles dirigidos a recuperar la posesión una vez el título legitimador pierde su eficacia, pues el Derecho Penal, una vez afirmada la presencia de un ilícito de tal naturaleza, debe aplicarse con carácter preferente. Si, por el

35 La mentada STS núm. 800/2014, de 12 de noviembre, declara que el "realizador de la ocupación" debe carecer "de título jurídico que legitime esa posesión, pues en el caso de que hubiera sido autorizado para ocupar el inmueble, aunque fuese temporalmente o en calidad de precarista, la acción no debe reputarse como delictiva, y el titular deberá acudir al ejercicio de las acciones civiles procedentes para recuperar su posesión". 
contrario, se exige una ocupación ilícita inicial, el mantenimiento posterior carece de autonomía o independencia: mantenerse significa seguir ocupando. Esta interpretación, dicho de otro modo, parece dejar sin ámbito de aplicación propio esta segunda modalidad delictiva.

Existe, sin embargo, una solución que, a mi juicio, resulta totalmente plausible: debe existir, sí, una ocupación ilícita inicial, es decir, sin título habilitante o legitimador de la posesión, pero solo en sentido objetivo; dicho de otra forma: el sujeto activo debe, en dicho sentido objetivo, ocupar sin autorización debida el inmueble; pero debe desconocer, cuando lo ocupa, que lo hace sin tal debida autorización; debe ocupar ilícitamente sin dolo, en la creencia de que sí existe un título posesorio inicial que autoriza su ocupación. Creer que se ocupa lícitamente no significa, evidentemente, que se ocupa lícitamente; pero sí impide afirmar que se actúa de forma dolosa (la ausencia de autorización debida es, en efecto, un elemento del tipo) y, por consiguiente, que se realiza el tipo penal en su doble dimensión objetiva y subjetiva: la conducta, en fin, es atípica, penalmente irrelevante.

Ahora bien, si la buena fe inicial desaparece por tener conocimiento el ocupador como consecuencia, por ejemplo, de un intento de lanzamiento judicial, de la inexistencia de autorización debida, de un título posesorio que legitima su ocupación, el mantenimiento de esta última se producirá contra la voluntad de su titular en los exactos términos exigidos por el artículo 245.2 del Código Penal. La citada buena fe inicial es sustituida por una mala fe sobrevenida: aunque en un principio no se ocupó ilegalmente de forma dolosa, el mantenimiento subsiguiente al conocimiento de dicha ilegalidad sí es doloso: el sujeto activo, en efecto, se mantiene en un inmueble ajeno con conocimiento de que no concurre la debida autorización y de la voluntad contraria del titular de aquel.

Como he adelantado, el mantenimiento en el inmueble contra la voluntad de su titular si cuenta, ahora, con un ámbito 
de aplicación propio: el sujeto activo, objetivamente, ocupó de forma ilícita, pero subjetivamente actuó sin dolo y, por tanto, de forma penalmente irrelevante; el posterior mantenimiento constándole dicha ilicitud o carencia de título legitimador y la voluntad opuesta del titular del inmueble colma todas las exigencias del tipo: la intervención penal ahora cobra sentido y lo hace distinguiendo los respectivos ámbitos de aplicación de sus dos modalidades típicas.

\section{Inmueble, vivienda o edificio ajenos}

El artículo 245.2 tipifica la ocupación de (o mantenimiento en) inmuebles, viviendas o edificios ajenos, exigiendo, además, que no constituyan morada, requisito, este, que requerirá nuestra independiente atención en el próximo apartado.

"Son bienes inmuebles" ${ }^{36}$, según el artículo 334 del Código Civil, los siguientes:

$1 .^{\circ}$ Las tierras, edificios, caminos y construcciones de todo género adheridas al suelo.

$2 .^{\circ}$ Los árboles y plantas y los frutos pendientes, mientras estuvieren unidos a la tierra o formaren parte integrante de un inmueble.

3. ${ }^{\circ}$ Todo lo que esté unido a un inmueble de una manera fija, de suerte que no pueda separarse de él sin quebrantamiento de la materia o deterioro del objeto.

4. ${ }^{\circ}$ Las estatuas, relieves, pinturas u otros objetos de uso u ornamentación, colocados en edificios o heredades por el dueño del inmueble en tal forma que revele el propósito de unirlos de un modo permanente al fundo.

5. Las máquinas, vasos, instrumentos o utensilios destinados por el propietario de la finca a la industria o explotación que se realice en un edificio o heredad, y que directamente concurran a satisfacer las necesidades de la explotación misma.

36 Así empieza precisamente el precepto. 
$66^{\circ}$ Los viveros de animales, palomares, colmenas, estanques de peces o criaderos análogos, cuando el propietario los haya colocado o los conserve con el propósito de mantenerlos unidos a la finca, y formando parte de ella de un modo permanente.

7. ${ }^{\circ}$ Los abonos destinados al cultivo de una heredad, que estén en las tierras donde hayan de utilizarse.

$8 .^{\circ}$ Las minas, canteras y escoriales, mientras su materia permanece unida al yacimiento, y las aguas vivas o estancadas.

9. ${ }^{\circ}$ Los diques y construcciones que, aun cuando sean flotantes, estén destinados por su objeto y condiciones a permanecer en un punto fijo de un río, lago o costa.

10. Las concesiones administrativas de obras públicas y las servidumbres y demás derechos reales sobre bienes inmuebles.

"Se reputan bienes muebles", sigue diciendo el artículo 335 del Código Civil, "los susceptibles de apropiación no comprendidos en el capitulo anterior, y en general todos los que se pueden transportar de un punto a otro sin menoscabo de la cosa inmueble a que estuvieren unidos".

¿Son estas definiciones vinculantes para el aplicador e intérprete del Derecho Penal? Reconocida la autonomía de este, la respuesta, claramente, es negativa, lo cual, por supuesto, no impide que, precisamente en virtud de dicha autonomía, decida atribuir a un determinado término el mismo significado que tiene en otro sector del ordenamiento jurídico.

Aunque diversos autores han considerado que el concepto de inmueble al que se refiere el artículo 245 es el propio del derecho civil y, por consiguiente, el acuñado por el mentado artículo $334 \mathrm{CC}^{37}$, es sin duda doctrina mayoritaria, y no existe

37 Vid., al respecto, JIMÉNEZ PARÍS, Usurpación pacifica de bienes inmuebles, ob. cit., pág. 420. Cita este autor diversa doctrina y, destacadamente, esta frase de VIVES ANTÓN/GONZÁLEZ CUSSAC ("Título XIII. Capítulo V", Comentarios al Código Penal de 1995, vol. II -arts. 234 a Disposiciones finales-, coord. Tomás Samuel Vives Antón, Tirant lo blanc, Valencia 1995, pág. 1204: "el objeto material, lo constituyen los bienes inmuebles 
jurisprudencia en sentido contrario, la que sostiene la independencia de ambos conceptos. La definición de bien mueble contenida en el propio Código Civil, con exclusión de la primera frase de su artículo 335, y un recorte de la segunda, es perfectamente válida en nuestro ámbito: son bienes muebles todos los que se pueden transportar de un punto a otro. Son bienes inmuebles, por el contrario, los así definidos por el citado artículo 334 no susceptibles de ser transportados de un lugar a otro.

Sostener que el concepto penal de inmueble debe identificarse con el Código Civil no solo no es necesario, sino, además, un sinsentido. Considerar que las máquinas, vasos, instrumentos o utensilios destinados por el propietario de la finca a la industria o explotación que se realice en un edificio o heredad son bienes inmuebles implica afirmar que pueden ser ocupados sin ánimo de lucro o apropiación y, pese a todo, constituir un delito, configurándose, así, como una suerte de hurto de uso de bienes inmuebles susceptibles de ser transportados, es decir, de bienes muebles en el sentido del artículo $234 \mathrm{CP}$, a menos que se sostenga que, por tratarse de bienes inmuebles, no pueden ser objeto material del delito de hurto. El resultado sería, en tal caso, sencillamente absurdo: dichas máquinas, vasos, instrumentos y utensilios no podrían ser objeto de hurto, pero sí de ocupación, que sería delictiva pese a no concurrir ánimo de lucro. Si concurriere este, no podría estimarse cometido un hurto; seguramente sí un delito de ocupación de inmuebles (susceptibles de ser transportados), que se cometería tanto si concurriere, como si no, ánimo de apropiación.

(números $1^{\circ}$ a $9^{\circ}$ del artículo 334 del Código Civil) y los derechos reales inmobiliarios $\left(n^{\circ} 10^{\circ}\right.$ del artículo 334 del Código Civil). Con acierto se ha señalado en la doctrina que el artículo 245 emplea los términos bienes inmuebles y derechos reales en el mismo sentido que les otorga el Derecho privado. La propuesta de Muñoz Conde y Bajo Fernández, en orden a excluir del concepto todo lo que sea susceptible de apoderamientono es viable, desde el momento en que la usurpación recae también sobre elementos que podrían ser objeto de hurto o de robo, pero que resultan, al igual que los demás componentes del inmueble, sencillamente ocupados". 
En realidad, pese a aquella defensa de una opción civilista de la concepción del bien inmueble, no existe una verdadera polémica al respecto, pues, como he adelantado, la jurisprudencia no la ha acogido en ningún caso.

El concepto de bien inmueble establecido por el Código Civil constituye, sin duda, una referencia normativa válida, pues el Derecho Penal forma parte de un ordenamiento jurídico, de un sistema de normas, y no puede desconocer la existencia de aquel, pero es preciso adaptarlo a los fines de este e interpretarlo en el seno del subsistema penal, en el cual el delito de hurto, por ejemplo, ofrece protección a bienes susceptibles de ser tomados por una tercera persona; y otro tanto hace el delito de robo, que tipifica el comportamiento de quien se apoderare de cosas muebles ajenas, es decir, e igualmente, susceptibles de forma natural de ser tomadas y transportadas.

En el ámbito del Derecho Penal son bienes inmuebles, por tanto, tomando dicho artículo 334 como base o referencia normativa, y de acuerdo con HUERTA TOCILDO, los siguientes: las tierras, edificios y construcciones no movibles y caminos $\left(334.1^{\circ}\right)$; las minas, canteras y escoriales mientras su materia permanezca unida al yacimiento (art. $334.8^{\circ}$ ) y los diques o construcciones no flotantes $\left(334.9^{\circ}\right)$, así como los derechos reales, siempre que su objeto sea un inmueble en sentido penal ${ }^{38}$.

Entendido de esta forma, el de bien inmueble es un concepto muy extenso, más amplio, por supuesto, que los de vivienda y edificio, comprensivo, además, en principio, de ambos. El edificio, sin duda, es, tanto en sentido civil como penal, un inmueble. La vivienda, por el contrario, no precisa ser, al menos en sentido penal, un bien inmueble, pues puede serlo, por ejemplo, una caravana.

38 O, desde otra perspectiva, "no son bienes inmuebles sino muebles, en Derecho penal, los enumerados en los apartados $1^{\circ}$ (edificios o construcciones que sean separables del suelo sin deterioro ni merma del objeto), $2^{\circ}, 3^{\circ}, 4^{\circ}, 5^{\circ}, 6^{\circ}, 7^{\circ}$, y $9^{\circ}$ (en lo tocante a diques y construcciones flotantes) [del art. $334 \mathrm{CC}$ ], constituyendo su aprehensión otras tantas modalidades de robo o hurto". Vid. HUERTA TOCILDO, Protección penal del patrimonio inmobiliario, ob. cit., pág. 50. 
BAUCELLS LLADÓS descarta que las caravanas, tiendas de campaña, barracas, casetas, barcos o vagones de trenes sean objeto de protección por el artículo 245, pues considera que deben tutelarse exclusivamente bienes inmuebles ${ }^{39}$. Este autor, por tanto, a diferencia de lo que veremos acto seguido, no restringe el concepto de inmueble exigiendo que se trate de una edificación que constituya vivienda, sino que limita este último concepto exigiendo que se trate de un bien inmueble. Restringe el ámbito de aplicación del tipo, por tanto, mediante una interpretación que opera en sentido inverso al que inmediatamente veremos.

Son numerosos los ejemplos de bienes inmuebles que suministra un análisis jurisprudencial: terrenos, tierras, jardines, almacenes, garajes, plazas de parking, amarres de puerto deportivo, caminos, casas de aperos, etc.

Esta amplia comprensión del término inmueble solo delimita sus límites externos, el marco, dicho de otro modo, que no puede superar su interpretación. Atribuir a dicho término una significación coincidente con dichos límites implica realizar una interpretación extensiva respetuosa con el principio de legalidad, pero no es obligada.

Así, por ejemplo, MIRAPEIX LACASA sostiene que " $e l$ concepto de «inmueble» hace referencia a las viviendas y edificios, en la medida en que estos dos términos, que le siguen en la redacción típica, tienen la función de restringir y definir su contenido" $"$. Afirma dicha autora que, "en efecto, los términos "vivienda" y "edificio" no añaden nada al concepto de inmueble, dado que el supuesto $1^{\circ}$ del mencionado art. 334 CC ya incluye ambos términos, en el marco del contenido del concepto

39 BAUCELLS LLADÓS, “Comentario al art. 245 del Código Penal”, ob. cit., pág. 719.

40 Vid. MIRAPEIX LACASA, Núria, La usurpación pacifica de inmuebles, Tesis doctoral dirigida por David Felip i Saborit i Mariona Llobet Anglí (codir. tes.). Universitat Pompeu Fabra (2016), pág. 45.

https://www.tesisenred.net/bitstream/handle/10803/385917/tnml. pdf? sequence $=1$ \&isAllowed $=\mathrm{y}$ 
de bien inmueble. Esto lleva a pensar que el hecho de que figuren, en el art. 245.2CP, al lado del término inmueble, tiene algún cometido más allá de la mera reiteración. En concreto, parece que desarrollan una función de limitación"41.

También opina en este sentido BORJA JIMÉNEZ, que afirma el art. 245.2 castiga el comportamiento tipificado en el art. 245.1 cuando no exista violencia o intimidación, "pero limitándose a vivienda o equiparada (inmueble o edificio) que no constituya la morada de sus titulares"42.

La tesis de la referida autora, preciso es reconocerlo, está bien fundamentada. Advierte MIRAPEIX LACASA que su interpretación "también es más acorde con el elemento gramatical. En virtud del mismo, si el legislador ha definido algún término expresamente para alguna materia, tendrá este significado legal en el marco de la misma y, en el resto, seguirá imperando su sentido natural y obvio, según el uso general. Considero que el significado común del término inmueble es precisamente el de vivienda o edificio. Dificilmente alguien no versado en el lenguaje jurídico va a considerar inmueble una carretera y aún menos un árbol frutal o los abonos destinados al cultivo de una heredad"43.

"También el elemento teleológico", sigue explicando MIRAPEIX LACASA, "apunta en la misma dirección. En este sentido, debe tenerse en consideración que el tipo estudiado se incluyó en el CP95 para frenar el avance del movimiento "okupa" que había proliferado de forma alarmante en los años 90. Este colectivo se centraba en la ocupación de viviendas, para habitar en ellas y de edificios, para crear "centros sociales»" 44 .

41 Vid. MIRAPEIX LACASA, Núria, La usurpación pacifica de inmuebles, ob. cit., págs. 47 y 48.

42 Vid. BORJA JIMÉNEZ, Emiliano, Derecho Penal. Parte Especial, coord. José Luis González Cussac, Tirant lo blanch, Valencia 2016, pág. 384.

43 Vid. MIRAPEIX LACASA, Núria, La usurpación pacifica de inmuebles, ob. cit., pág. 48.

44 "En función de lo expuesto", concluye MIRAPEIX LACASA, "coincido plenamente con la postura que defiende la necesidad de configurar un con- 
Muy recientemente ha sostenido la Audiencia Provincial de Santa Cruz de Tenerife (Sección $2^{\mathrm{a}}$ ) en su Sentencia núm. 230/2018, de 28 de junio, denunciada la aplicación indebida del art. 245.2 del CP, que este precepto es aplicable "a viviendas y edificios", así como "a inmuebles equiparables a los anteriores, pues en todo caso debe excluirse que constituyan morada", por lo que "no resulta aplicable a la ocupación de fincas o predios, a las que sí que se refieren con una referencia genérica a las "cosas inmuebles" o, de forma más precisa, como "heredades" los arts. 245.1 y 246 CP". "La ocupación de fincas", en suma, "al contrario de lo que sucede con las viviendas o edificaciones que no constituyan morada, solamente es delictiva cuando se lleva a cabo con violencia o intimidación (art. 245.1 CP)".

cepto autónomo de bien inmueble a efectos del derecho penal. Sin duda entiendo que deben quedar excluidos los bienes susceptibles de transporte, aprehensión y sustracción. Asimismo, me adhiero a la interpretación que hace nuestra jurisprudencia de bien inmueble a los efectos del delito estudiado y considero que su significado se integra a partir de los términos "vivienda" y "edificio". En consecuencia con lo anterior, considero que respecto del tipo estudiado el concepto de bien inmueble no abarcaría ni siquiera la totalidad de los denominados "inmuebles por naturaleza". En este sentido, cuando más adelante se aborde cuál es a mi entender el alcance del verbo típico "ocupar", expondré que el mismo significa: "tomar posesión de un espacio". Así, no sería inmueble, a los efectos del precepto estudiado, todo aquel bien que no consistiera en un espacio cerrado. Por otra parte, como se verá cuando me refiera al momento consumativo, a mi parecer la toma de posesión se completa: 1. Cuando se quiebran las barreras dispuestas por el propietario del bien para impedir el uso y disfrute de terceros ajenos. 2. Cuando se disponen los medios necesarios para posibilitar el uso y disfrute en exclusiva. De esta forma, quedaría fuera del contenido del concepto de inmueble todo aquel bien respecto del cual no se pueda tomar posesión en los términos expresados. Respecto a las parcelas de terreno, en función de lo expuesto hasta el momento, únicamente sería típica la ocupación de aquéllas que dispusieran de medios de exclusión de terceros, que fueran adyacentes a un edificio o vivienda y que pudieran reputarse como parte de éstos. Al respecto de la ocupación del terreno perteneciente a una finca rústica militar, la STS 800/2014 entiende que se trata de un caso de usurpación de inmuebles. El terreno en cuestión se hallaba vallado $y$, para entrar en el mismo, los usurpadores destruyen la cadena que impide el acceso". Vid. MIRAPEIX LACASA, Núria, La usurpación pacifica de inmuebles, ob. cit., pág. 48. 
A mi juicio, debe rechazarse la interpretación restrictiva sugerida por MIRAPEIX LACASA. Aunque según el diccionario de la Real Academia el término inmueble significa, en principio, casa, es decir, edificio para habitar, asociado al término bien adquiere un nuevo significado: según dicho diccionario, son bienes inmuebles las "tierras, edificios, caminos, construcciones y minas, junto con los adornos o artefactos incorporados, así como los derechos a los cuales atribuye la ley esta consideración".

La Ley, como hemos visto, concretamente el Código Civil, define el concepto bien inmueble, y lo hace en términos muy generosos, no desconocidos por el Código Penal, pero adaptado por sus aplicadores a esta disciplina normativa. Si los bienes pueden clasificarse en muebles e inmuebles, y los primeros son aquellos susceptibles de ser trasladados, objeto de atención específica de los delitos de hurto y robo, los segundos son todos los demás. El propio diccionario de la Real Academia amplía, por otra parte, como hemos visto, el significado inicialmente atribuido al término inmueble. Una interpretación literal de este no exige, por tanto, excluir bienes que no sean casas o edificios para habitar.

Si el artículo 245 del Código Penal diferencia tres objetos materiales es preciso dar sentido a dicha distinción y no suprimir uno de ellos, el más amplio, por cierto, interpretando que, pese a su expreso reconocimiento, la ley solo pretende proteger los inmuebles que sean edificios y, además, viviendas. Se realiza, de esta forma, una doble restricción interpretativa que elimina la distinción impuesta por el legislador. Es preciso reconocer, dicho ello, que si bien el término vivienda es susceptible de referirse a bienes muebles (tendría pleno sentido, por ello, dada la diferenciación impuesta por la ley, conceder un ámbito de aplicación propio al término vivienda más allá de los límites impuestos por el término inmueble), el concepto edificio nada añade a aquel, por lo que, desde esta perspectiva, resulta redundante. Puede considerarse, eso sí, una llamada de atención, una 
apelación al intérprete, que no debe limitar la aplicación del tipo penal a la ocupación de viviendas, sino extenderla a la de edificios que carezcan de dicha condición.

Dicho ello, es obligado reconocer que si bien la mayoría de condenas impuestas por el delito previsto y penado en artículo 245 del Código Penal traen causa de la ocupación de un edificio constitutivo de vivienda, no son excepcionales los pronunciamientos que incluyen en dicha figura penal la ocupación de inmuebles que no tienen la consideración ni de edificio ni de vivienda.

Especialmente llamativo resulta el supuesto del que se ocupa el Auto núm. 433/2005, de 19 de diciembre, dictado por la Sección $2^{\mathrm{a}}$ de la Audiencia Provincial de Castellón. Según esta, la ocupación ilegitima de una plaza de amarre en un puerto deportivo "podría tener encaje - no fácil- en el tipo del art. 245.2 del CP, porque, aunque se refiere el tipo penal a «inmueble», $y$ en principio pareciere no tener cabida dentro de tal concepto un amarre en un puerto deportivo, que no sería más que el derecho a utilizar un determinado espacio en el agua, que conlleva unos derechos de disfrute, no sería descartable si nos atenemos al tenor del art. 334. 9 del CC. Ha de conocerse entonces como es el amarre afectado, si participa de lo que es una "construcción ... destinada por su objeto y condiciones a permanecer en un punto fijo de un río, lago o costa".

La Sección $2^{\mathrm{a}}$ de la Audiencia Provincial de Vizcaya, en su Sentencia núm. 90145/2014, de 9 de abril, afirma, "en cuanto al uso u ocupación de una plaza de garaje ajena", que "tal acción sería incardinable en el art ${ }^{\circ} 245.2$ del Código Penal, si tuviera cierta vocación de permanencia". El hecho de que no se trate de una vivienda no resulta obstáculo, por tanto, para aplicar el artículo 245.2 del Código Penal.

Mediante Auto núm. 705/2011, de 24 de octubre, la Sección $16^{\mathrm{a}}$ de la Audiencia Provincial de Madrid revoca la resolución recurrida, que había acordado el sobreseimiento provisional de las actuaciones, a las que se había dado inicio por la denuncia 
de los siguientes hechos: la ocupación de una plaza de garaje sin autorización durante dos años. El juzgador de instrucción consideró posible la existencia de un delito de usurpación del artículo 245.2 pero sobreseyó la causa por estimar que "como existe controversia respecto de la existencia o no de un contrato de arrendamiento entre las partes, en virtud del principio un dubio pro reo, es procedente el sobreseimiento". La Audiencia Provincial declara, "examinado lo actuado", que los hechos denunciados, en efecto, "podrían ser constitutivos de un delito de usurpación de bien inmueble sin la autorización del titular del art. 245.2". "La denunciante", se explica, "niega haber celebrado contrato alguno, ni verbal ni por escrito con el denunciado, ni haberle permitido la ocupación de su plaza de garaje. Ocupación que se dilató en el tiempo por dos años". "La ocupación", sigue diciendo la Audiencia Provincial, "ha sido reconocida por el imputado, si bien él manifiesta que hicieron un contrato verbal y que pagaba la renta en metálico a la arrendadora. Sin embargo, el imputado no sabe ni siquiera el nombre de su arrendadora, refiriéndose a ella como una "mujer rubia y mayorcita", no sabe decir cuál es el domicilio de ésta, mencionando dos calles, de las que no sabe ni el número ni el piso ni la letra, a pesar de que dice que llamaba al telefonillo y ella bajaba para pagarla. Tampoco tiene número de teléfono, ni ha acreditado el pago de cantidad alguna, ni ha aportado recibo alguno".

"Ante todas estas circunstancias", concluye el Auto, "entendemos que existen indicios de criminalidad para seguir adelante con el procedimiento, no siendo esta fase de instrucción el momento adecuado para aplicar el principio in dubio pro reo, que deberá valorarse en el acto del juicio oral".

También curioso resulta el supuesto sometido al enjuiciamiento de la Audiencia Provincial de Madrid (Sección 23a), la cual, mediante Sentencia núm. 47/2008, de 21 de abril, declara la absolución por un delito de usurpación: "los hechos concretos se hubieran cometido a partir de la colocación de las vallas de publicidad en una serie de fincas y sería necesario que con la misma se estuviera perturbando en la posesión a los legítimos 
propietarios de las fincas, cosa que realmente en el presente caso no se ha acreditado, pues los propietarios de las mismas en unos casos no han hablado de perturbación alguna, o bien, en otros casos, ni siquiera tenían conocimiento de la colocación de tales vallas, salvo Rubén que llegó a interponer una demanda civil en un Juzgado de Primera Instancia, que desestimó la pretensión deducida en dicho procedimiento, razón por la que ni siquiera en este caso se puede hablar propiamente de perturbación en la posesión que realmente pueda dar lugar o que tenga un contenido específico de carácter ilícito que pudiera dar lugar a la comisión del delito de usurpación previsto en el número 2 del artículo 245 del vigente C. Penal".

Como puede apreciarse, la absolución no es consecuencia de la imposible adjetivación del hecho como ilícita ocupación de un inmueble, sino de la falta de acreditación de la siempre necesaria afección del bien jurídico.

La Sentencia núm. 427/2011, de 14 de diciembre, de la Sección $2^{\mathrm{a}}$ de la Audiencia Provincial de Cáceres, estima constitutiva de un delito de usurpación del artículo 245.2 la ocupación temporal (durante unas obras) de terrenos mediante tuberías con creación por vía de hecho de una servidumbre de acueducto.

La Audiencia Provincial de Cuenca, mediante su Sentencia núm. 6/2003, de 13 de enero, confirmó la existencia de un delito de ocupación del artículo 245.2 en un caso en que tuvo lugar el enterramiento de despojos de animales de matadero en una finca ajena.

El Juzgado de lo Penal de Cuenca había dictado sentencia declarando probados los siguientes hechos: "El acusado Baltasar (...) prestando sus servicios y realizando labores para el Matadero de Conejos, AGRUMAR, SL, sito en la calle Carretera Vieja de Valencia s/n de Campillo de Altobuey, utilizó durante el año 1.998 y los primeros meses de 1.999, la finca xxxx, parcela yyyyy del polígono zzzz del Término municipal de Campillo de Altobuey, con la finalidad de enterrar los despojos del matadero cavando para ello un número importante de zan- 
jas en la mencionada finca, todo ello, sin la autorización de su legítimo propietario Carlos Miguel .

Como consecuencia de la mencionada utilización se produjeron una serie de daños en la citada finca consistentes en el deterioro de la tierra para el cultivo a causa de los malos olores y molestias que se producen durante el laboreo de las tierras, y el abultamiento del terreno como consecuencia de las zanjas practicadas y posterior relleno de las mismas. Daños que fueron valorados, según Informe Pericial de Perito designado por el Juzgado de Instrucción en 750.000 pesetas (4.507,59 euros), 500.000 pesetas (3.005,06 euros) en concepto de valor, por los daños ocasionados y 250.000 pesetas (1.502,53 euros) en concepto de valor de utilidad reportada".

La Audiencia Provincial de Cuenca, como he adelantado, desestimó el recurso de apelación interpuesto contra la sentencia dictada por el Juzgado de lo Penal, que condenó al autor de los hechos por sendos delitos de usurpación (pena de cuatro meses multa) y continuado de daños.

"Teniendo en cuenta que la realización de obras en parcela ajena constituye un uso posesorio de lo de otros, de carácter permanente y excluyente del uso del antiguo poseedor, es admisible en principio que la destrucción de la antigua acequia y la ocupación permanente de terreno constituya el delito del art. 245.2 del Código Penal". En estos términos se expresa la Sección $3^{\text {a }}$ de la Audiencia Provincial de León en su Auto núm. 732/2017, de 13 de junio.

La Sección $3^{\text {a }}$ de la Audiencia Provincial de Valencia, en su Sentencia núm. 43/2016, de 27 de enero, estima constitutivos de delito de usurpación del artículo 245.2, condenando la condena impuesta por la resolución recurrida, los siguientes hechos: "Ceferino, al menos entre los meses de enero y abril de 2013, se encontraba viviendo en un terreno rural sito en el camino Fuentes (Junto al Cementerio de Benimaclet) del término municipal de Valencia. El propietario del terreno no autorizó la ocupación del terreno ni el cultivo que se hizo en el mismo". 
La Audiencia Provincial de Madrid (Sección 29a), mediante Sentencia núm. 102/2018, de 26 de febrero, confirma la condena por delito del artículo 245.2 de la ocupación de una finca mediante la instalación en ella de una caravana "a sabiendas de que no podía hacerlo por no ser propietario ni titular de ningún derecho sobre" ella. A la alegación formulada por la parte recurrente de que la parcela no es un inmueble y el hecho, por tanto, no está tipificado en el artículo 245.2, responde la Audiencia Provincial que no puede compartirse tal tesis, citando al respecto, como fundamento de autoridad, la citada Sentencia del Tribunal Supremo núm. 800/2014, de 12 de noviembre.

Esta sentencia se ha constituido, en efecto, como ya había adelantado, en una referencia jurisprudencial en materia de interpretación judicial del artículo 245.2 del Código Penal. La Sala de lo Civil y Penal del Tribunal Superior de Justicia de Andalucía consideró constitutiva de un delito de dicho precepto la ocupación no violenta de una finca rústica militar durante dieciocho días con finalidad de protesta social. Condenada varias personas también por delito de desobediencia, el Tribunal Supremo las absuelve "dejando subsistentes los demás pronunciamientos de la sentencia de instancia, especialmente la condena de los cinco recurrentes por delito de usurpación".

\section{5. «Que no constituyan morada»}

El inmueble, la vivienda o el edifico ajenos ocupados no deben constituir, como especifica el artículo 245.2, morada, pues si lo fueren debería aplicarse el delito de allanamiento previsto y penado en los artículos 202 y 203, que son preceptos principales en virtud de la regla de subsidiariedad expresa prevista en aquel.

La amplitud del ámbito de aplicación del artículo 245.2 dependerá de la que se conceda al término morada: concebido este de forma muy generosa, se reduce el citado ámbito de aplicación del delito de ocupación; concebido de forma restrictiva, se amplía este último. 
BAUCELLS LLADÓS considera que los delitos de usurpación exigen la concurrencia de ánimo de lucro y que la actuación se lleve a cabo en concepto de dueño. Estima, además, que el concepto morada debe ser interpretado en relación con el bien jurídico protegido, es decir, el patrimonio. Considera, por otra parte, que los bienes inmuebles a los que hace referencia el artículo 245.2 no deben haber estado ocupados jamás o deben estar abandonados. El art. 245.1, por el contrario, sí puede dar acogida a inmuebles que constituyan morada, pues esta es una exigencia exclusiva del art. 245.2. En estas circunstancias, concluye, el actuar en concepto de dueño o no es lo que permitirá "delimitar los delitos de usurpación de los delitos de allanamiento de morada". "Para poder tipificar la conducta como delito de usurpación (art. 245.1 CP) o allanamiento de morada (art. $202 \mathrm{CP}$ ), será necesario recurrir al concreto ánimo del autor, es decir, demostrar si su ánimo era el de subrogarse en la posición del titular o violar la intimidad domiciliaria"45.

El Código Penal no define el término morada, no coincidente, por otra parte, con el concepto casa habitada definido por el artículo 241.2. Dice este que "se considera casa habitada todo albergue que constituya morada de una o más personas, aunque accidentalmente se encuentren ausentes de ella cuando el robo tenga lugar". Dicho de otro modo, si la ausencia de aquellas personas no es meramente accidental, la morada no será, a efectos de dicho artículo 241.2, casa habitada. La agravación impuesta por este artículo no halla su fundamento, por tanto, en la lesión de la intimidad, sino en la posibilidad de que hubiere personas en la morada y ello las ponga en peligro.

Según el Diccionario de la Real Academia Española, la morada es una «estancia de asiento o residencia algo continuada en un lugar» o un "lugar donde se habita». Si de acuerdo con aquella primera acepción se requiere una estancia algo continuada, la segunda se conforma con exigir que se habite en el lugar. No es preciso que ello se haga, por tanto, de forma algo

45 Vid. BAUCELLS LLADÓS, “Comentario al art. 245 del Código Penal”, ob. cit., pág. 729. 
continuada. El propio Diccionario de la Real Academia se refiere a la morada también como un «espacio cerrado y separado del mundo exterior en el que se desarrolla la vida privada, destinado a pernoctar y en uso actual, aunque no necesariamente permanente»

En su Sentencia núm. 809/2012, de 25 de octubre, afirma el Tribunal Supremo que, "como señalaba la ya veterana STS de 15 de febrero de 1997, luego reiterados los criterios allí expuestos en otras numerosas resoluciones, teniendo en cuenta que el derecho fundamental de la inviolabilidad del domicilio está muy ligado al de la protección de la intimidad (artículo 18.1 y 2, de la Constitución), la doctrina de este Tribunal Supremo ha concebido el domicilio de manera muy amplia, llegándose a definir, con carácter general, como "cualquier lugar cerrado en el que pueda transcurrir la vida privada, individual o familiar, aún ocupada temporal o accidentalmente»".

La interpretación amplia o extensiva del concepto morada es, sin duda, superior al significado atribuido en el lenguaje ordinario a este término, pero no a su tenor literal. Se trata, expresado con otras palabras, de una verdadera interpretación y no de una analogía invasora de competencias legislativas y, por consiguiente, lesiva del principio de legalidad. En el lenguaje común difícilmente se atribuirá la condición de morada a una habitación de hotel en la que se pasa una o pocas noches o a una tienda de campaña, pero no puede afirmarse que sobrepase el tenor literal del concepto morada.

Advierte también el Tribunal Supremo que la referida interpretación extensiva viene impuesta por la necesidad de dar efectiva protección penal al derecho fundamental a la inviolabilidad del domicilio y a la intimidad, estrechamente ligada a aquél. Una interpretación declarativa o restrictiva impediría, dicho de otro modo, una adecuada protección del bien jurídico protegido por el delito de allanamiento de morada.

Interesantes resultan, al respecto, las reflexiones que siguen, en la misma sentencia citada, a las trascritas, cuyos aspectos 
más destacados subrayaré: "Por otra parte, y como ha sido puesto de relieve por la doctrina, la casuística en esta materia es innumerable, "ya que la casación ha obligado al citado tribunal a enfrentarse a los conceptos más variopintos de domicilio», aunque, eso sí, partiendo casi siempre de la base de su utilización como "morada» en el sentido amplio de la palabra, con independencia de "su sencillez o modestia, estado de conservación y número de enseres que en él se encuentren». Esa casuística nos enseña que por domicilio puede entenderse desde la vivienda habitual o esporádica (lo que se ha dado en llamar segunda vivienda), pasando por una habitación con puerta independiente y sólo dotada de un televisor y una caja para sentarse, o una simple chabola habitada, hasta llegar a una tienda de campaña, una "roulotte", o una habitación de hotel. (Sentencias, entre otras, de 26 de junio y 17 de septiembre de 1993, 18 de febrero, 23 de mayo, 15 de octubre y 15 de diciembre de 1994). Por el contrario, y en general, no tienen ese concepto los locales comerciales y de esparcimiento o los almacenes, a no ser que unos u otros sean anexos a la vivienda.

Por eso, el Tribunal Constitucional ya declaró en su sentencia 22/84 que el derecho a la inviolabilidad de domicilio se concreta en la posibilidad de cada ciudadano de erigir ámbitos privados, es decir, que excluyen la observación de los demás y de las autoridades del Estado. Tal derecho se deriva directamente del derecho al libre desarrollo de la personalidad (artículo 10.1 de la CE). Consecuentemente, la protección del domicilio no es sino un aspecto de la protección de la intimidad que sirve al libre desarrollo de la personalidad. De ellos se deduce que el domicilio, en el sentido de la Constitución, no sólo es el lugar donde se pernocta habitualmente o donde se realizan otras actividades cotidianas habituales, sino también el ámbito cerrado erigido por una persona con objeto de desarrollar en él alguna actividad. En este sentido se ha dicho en la STC 22/84 (F. ${ }^{\circ} \mathrm{J}^{\circ}{ }^{\circ}$ ) que el derecho a la inviolabilidad del domicilio "constituye un auténtico derecho fundamental de la persona, establecido, según hemos dicho, para garantizar el ámbito de 
privacidad de ésta, dentro del espacio que la propia persona elige y que tiene que caracterizarse precisamente por quedar exento o inmune a las invasiones o agresiones exteriores, de otras personas o de la autoridad pública. Como se ha dicho acertadamente -continúa la STC-, el domicilio inviolable es un espacio en el cual el individuo vive sin estar sujeto necesariamente a los usos y convenciones sociales y ejerce su libertad más intima. Por ello-concluye-, a través de este derecho no sólo es objeto de protección el espacio físico en símismo considerado, sino lo que en él hay de emanación de la persona y de esfera privada de ella».

Y por eso también esta Sala ha establecido de manera especifica que, "por el contrario, no integra el concepto de vivienda, el local comercial o de esparcimiento (bares, tabernas, pubs, restaurantes, tiendas, locales de exposición, almacenes, etc.) (Cfr. SS. de 11 de junio de 1991, 19 de junio y 5 de octubre de 1992, y la de 21 de febrero de 1994), sencillamente porque no lo son al estar esencialmente destinados a estar abiertos al público y esto es así porque el derecho fundamental proclamado en el artículo 18.2 de la Constitución, protege como antes se dijo, la "intimidad" como valor esencialísimo, que para nada se proyecta sobre bienes materiales en sí ni en defensa de su propiedad".

En la jurisprudencia, en efecto, hallamos una enorme casuística al respecto, pudiéndose concluir, por ejemplo, que las viviendas de recreo o segundas residencias ${ }^{46}$ son morada. Obviamente es precisa una actualidad de su uso, que, como hemos visto, no debe ser permanente.

Algunas resoluciones, pese a todo, excluyen la existencia de un delito de allanamiento de morada cuando se entra en una segunda residencia. Este es el caso, por ejemplo, de la Sentencia núm. 330/2017, de 30 de junio, de la Sección $2^{\mathrm{a}}$ de la

46 Como apunta la referida STS núm. 809/2012, de 25 de octubre.

47 Como "esta Sección ha venido a mantener en anteriores ocasiones (SAP Tarragona de 8 de octubre de 2015)". 
Audiencia Provincial de Tarragona, que afirma ${ }^{47}$ que "en supuestos de viviendas de vacaciones o de segunda residencia, estas no merecen la consideración de domicilio a los efectos de que la conducta puede tener encaje en el delito de allanamiento de morada previsto en el artículo 202 del Código Penal, como ocurre en el caso analizado"48. Rechazada la consideración de morada del inmueble afectado y, por consiguiente, excluida la aplicación del artículo 202, la Audiencia Provincial de Tarragona estima cometido un delito de usurpación de bien inmueble del artículo 245.249: "en el presente supuesto, por tanto, la vivienda no constituía morada, por lo que nos encontraríamos ante esta última figura delictiva-ocupar sin autorización debida, una vivienda que no constituye morada-".

Dicho ello, considera la citada Audiencia que no se produce indefensión pese a que finalmente imponga pena por un delito que no había sido objeto de acusación: "el delito de allanamiento y el delito de usurpación por ocupación sin autorización de una vivienda son delitos heterogéneos, si bien con elementos homogeneizantes, de tal forma que en base al factum de las actuaciones, ninguna indefensión se le genera a la parte recurrente el hecho de que se le haya originariamente acusado por un delito de allanamiento y pudiera ser condenada finalmente por un delito de usurpación del artículo 245.2 del Código Penal".

La propia Audiencia Provincial de Tarragona (Sección $4^{\mathrm{a}}$ ), en Sentencia núm. 193/2008, de 19 de mayo, había sostenido lo contrario: "En cuanto al concepto de morada ajena,

48 "Así hemos mantenido que atendiendo al bien jurídico protegido, en el delito de allanamiento se protege como valor constitucional la intimidad personal y familiar, debiendo ser el derecho de las personas a la intimidad la clave con que debe ser interpretado el artículo 202, de suerte que el elemento objetivo del tipo descrito en esta norma debe entenderse puesto, siempre que la privacidad resulte lesionada gravemente amenazada, lo que inevitablemente ocurrirá cuando alguien entra en la vivienda de una persona, cualquiera que sea el móvil que a ello le induzca, sin su consentimiento expreso o tácito".

49 Los acusados habían entrado en el inmueble no antes del 25 de agosto de 2015 y permanecieron en él hasta el 17 de septiembre. 
debemos entender como tal, el recinto, generalmente cerrado y techado, en el que el sujeto pasivo y sus parientes próximos, habitan, desarrollan su vida íntima y familiar, comprendiéndose dentro de dicho recinto, dotado de especial protección, no sólo las estancias destinadas a la convivencia en intimidad, sino cuantos anejos, aledaños o dependencias constituyan el entorno de la vida privada de los moradores, indispensable para el desenvolvimiento de dicha intimidad familiar, y que, de vulnerarse mediante la irrupción, en ellos, de extraños, implica infracción de la intangibilidad tutelada por la Ley, por lo que quedan incluidas también con claridad las viviendas de recreo, o de segunda residencia, por cuanto en estas cabe apreciar también la voluntad de exclusión de terceras personas del ámbito de la privacidad personal".

Esta última sentencia da cabida en el término morada, como puede observarse, a "cuantos anejos, aledaños o dependencias constituyan el entorno de la vida privada de los moradores, indispensable para el desenvolvimiento de dicha intimidad familiar".

La Sentencia núm. 584/2018, de 1 de octubre, castiga incluso una conducta de allanamiento de balcón: "Ahora bien, la estancia en el balcón contra la voluntad de la moradora denunciante integra por si misma el delito de allanamiento de morada, dado que el balcón es una dependencia de la casa habitada según la interpretación auténtica que hace el artículo 241 del Código penal, e indudablemente forma parte del ámbito de privacidad de la vivienda, en razón de lo cual puede ser sancionado en la segunda instancia por la homogeneidad que presenta con el delito complejo del robo con fuerza en las cosas en casa habitada, pues forma parte del mismo junto con el acto del apoderamiento" 50 .

50 "El principio de contradicción se respeta completamente en esta diferencia puesto que la entrada en el balcón ha sido uno de los elementos de valoración de la prueba hasta el punto de haber sido reconocido por el apelante como cierto". Vid. Sentencia núm. 584/2018, de 1 de Octubre, de la Sección $4^{\mathrm{a}}$ de la Audiencia Provincial de Valencia. 
La aproximación al concepto morada, en fin, debe realizarse, ausente su definición legal e, incluso, jurisprudencial, de forma casuística ${ }^{51}$.

Como pone de manifiesto SANZ MORÁN, "ha quedado definitivamente zanjado el problema de si constituye morada la habitación de hotel o pensión, ocupada de manera ocasional" 52 . Sumamente actuales son las siguientes palabras de dicho autor: "sigue, sin embargo, abierta, en el Código penal de 1995, la controvertida cuestión de si el concepto de morada comprende también las dependencias anejas (bodegas, garajes, patios, etc.)" ${ }^{\prime 53}$.

51 Que, como hemos visto, el Tribunal Supremo califica como "innumerable".

52 "La doctrina y jurisprudencia mayoritarias venian dando una respuesta afirmativa, pues, como acabamos de recordar, el carácter temporal de la ocupación no obsta a la actualidad del uso, en cuanto requisito del concepto de morada. La cuestión ha sido objeto de consideración, muy recientemente -si bien, de nuevo, a propósito del concepto constitucional de domicilio-, en la STC 10/2002, de 17 de enero, donde se concluye la inconstitucionalidad del artículo 557 de la Ley de Enjuiciamiento Criminal, en el que precisamente se negaba la condición de domicilio «de los que se encuentren o residan en ellas accidental o temporalmente» a las «tabernas, casas de comidas, posadas y fondas», siéndolo sólo «de los taberneros, hosteleros, posaderos y fondistas que se hallen a su frente y habiten alli con sus familias en la parte del edificio a este servicio destinada». Según leemos en la mencionada resolución, "ni la accidentalidad, temporalidad o ausencia de habitualidad del uso de la habitación del hotel, ni las limitaciones al disfrute de las mismas que derivan del contrato de hospedaje, pueden constituir obstáculos a su consideración como domicilio de los clientes del hotel mientras han contratado con éste su alojamiento en ellas. Siendo las habitaciones de los hoteles espacios aptos para el desarrollo o desenvolvimiento de la vida privada, siempre que en ellos se desarrolle, constituyen ámbitos sobre los que se proyecta la tutela que la Constitución garantiza en el art. 18.2». Conviene insistir en que, por más que la sentencia se refiera al concepto constitucional de domicilio, lo mismo vale para el concepto jurídico penal de morada, dado que el Tribunal Constitucional viene interpretando aquél, como ya vimos, a la luz de éste". Vid. SANZ MORÁN, Ángel J., El allanamiento de morada, domicilio de personas jurídicas y establecimientos abiertos al público, Tirant on line, Valencia 2006, documento TOL971.926.

53 Vid. SANZ MORÁN, Á. J., El allanamiento de morada, domicilio de personas jurídicas y establecimientos abiertos al público, ob., cit., documento TOL971.926. 
"Nadie discute, finalmente", sigue diciendo SANZ MORÁN, "que el concepto de morada en modo alguno puede comprender los espacios comunes de un inmueble (portales, escaleras, pasillos comunes a varias viviendas, etc.) '"54.

La jurisprudencia también ha considerado, como hemos visto $^{55}$, que era posible adjetivar como moradas auto caravanas, chabolas, tiendas de campaña, los camarotes de un barco o, incluso, el jardín circundante a un chalet.

Este último es el caso, por ejemplo, de la Sentencia núm. 134/2012, de 4 de marzo, de la Sección $1^{\text {a }}$ de la Audiencia Provincial de Valencia. En dicha resolución se plantea este Tribunal la cuestión de la condición de morada del jardín que circunda la vivienda, ofreciendo esta respuesta: "Como señala la STS de 17 de noviembre de 2000 citada, la morada constituye generalmente un espacio cerrado y techado, lo que no excluye la inclusión en el concepto de morada del jardín circundante a la vivienda e integrado en el perímetro que delimita y separa la vivienda y sus anexos de la vía pública, que se comprende en el concepto morada, dotado de especial protección, no sólo en cuanto a las estancias destinadas a la convivencia en intimidad, sino cuantos anejos, aledaños o dependencias constituyan el entorno de la vida privada de los moradores, indispensable para el desenvolvimiento de dicha intimidad familiar, lo que consecuentemente ha de entender incluido el jardín que rodea la vivienda y que está protegido del exterior por una valla en el caso presente, delimitando asi también a nivel físico la extensión de la morada $y$ diferenciándolo del ámbito público que queda extramuros. El propio Tribunal Supremo en sentencia de 4 de noviembre de 2002 consideraba especificamente, el jardin circundante de un chalet-como nos ocupa en el caso presente-, como parte del domicilio y señalaba «la entrada y registro, en los términos an-

54 Vid. SANZ MORÁN, Á. J., El allanamiento de morada, domicilio de personas jurídicas y establecimientos abiertos al público, ob. cit., documento TOL971.926.

55 Vid., una vez más,la referida STS núm. 809/2012, de 25 de octubre. 
teriormente expuestos, debe ser considerada ilícita: el menor no podía consentir una diligencia como la que se practicó (tenía catorce años); el jardín circundante a un chalet debe ser considerado como parte del domicilio de su titular legítimo, en donde ejerce su intimidad, aunque la puerta de acceso al mismo esté abierta». En consecuencia, la recurrente cometió actos constitutivos del delito de allanamiento de morada".

\section{La limitación del ámbito de aplicación trazado por el} tenor literal de la ley: el bien jurídico protegido y su afección

El tenor literal del artículo 245.2 es, en suma, extremadamente amplio. Esta figura delictiva, según aquel precepto, es aplicable a toda ocupación, sin autorización debida, y a todo mantenimiento, contra la voluntad de su titular, de los siguientes bienes:

- un inmueble, fuere o no una vivienda o un edificio: terrenos, garajes, jardines, etc.

- una vivienda, fuere o no un inmueble o un edificio: caravanas, tiendas de campaña, etc.

- un edificio, fuere o no una vivienda: almacenes, casas de aperos, etc.

El referido tenor literal tolera, además, que el mantenimiento contra la voluntad del titular del bien sea posterior a una ocupación inicial lícita cuyo título legitimador ha visto extinguidos sus efectos.

¿Son todas las conductas toleradas por el tenor literal del artículo 245 número 2 , efectivamente, delictivas?

6.1. El principio de exclusiva protección de bienes jurídicos: límite y función del Derecho Penal

La intervención penal, como nos enseña el principio de exclusiva protección de bienes jurídicos, debe producirse 
únicamente para ofrecer tutela a estos últimos ${ }^{56}$. Esta imposición, como indica SILVA SÁNCHEZ, constituye una garantía fundamental del Derecho Penal moderno ${ }^{57}$, derivándose de ella importantes restricciones de la punibilidad ${ }^{58}$.

Pese a que la Constitución ${ }^{59}$ no contiene referencia expresa alguna al principio de exclusiva protección de bienes jurídicos, éste constituye la manifestación de la confluencia de diversos principios garantistas, entre los que destaca el de proporcionalidad en sentido amplio o prohibición de exceso, que caracteriza la idea de justicia en el marco de un Estado de Derecho ${ }^{60}, \mathrm{y}$, por tanto, en el ámbito penal ${ }^{61}$ : la actuación punitiva

56 "El Derecho Penal de un Estado social ha de justificarse como sistema de protección de la sociedad. Los intereses sociales que por su importancia pueden merecer la protección del Derecho se denominan «bienes jurídicos». Se dice, entonces, que el Derecho Penal sólo puede proteger «bienes jurídicos». La expresión "bien jurídico» se utiliza en este contexto en su «sentido politico-criminal» de objeto que puede reclamar protección jurídico-penal, en contraposición a su «sentido dogmático», que alude a los objetos que de hecho protege el Derecho Penal vigente". Vid. MIR PUIG, S., Derecho Penal. Parte General, Reppertor, Barcelona 2002, pág. 124.

57 Vid. SILVA SÁNCHEZ, J. M., Aproximación al Derecho Penal contemporáneo, J.M. Bosch, Barcelona 1992, pág. 267.

58 Un ejemplo importante de dichas restricciones es la exclusión, según observa ROXIN, de las meras inmoralidades del Derecho Penal. Vid. ROXIN, Derecho Penal. Parte General, Tomo I, Civitas, Madrid 1997, pág. 52.

59 Ni el Código Penal, como observa AGUADO CORREA, T., El principio de proporcionalidad en Derecho Penal, Derecho Reunidas, Madrid 1999, pág. 163.

60 Así, MUÑoz CONDE, F./GARCÍA ARÁn, M., Derecho Penal. Parte General, Tirant lo blanch, Valencia 2002, pág. 85.

61 "En Derecho español, puede afirmarse su vigencia a partir del artículo $1^{\circ}$ de la Constitución, no sólo en tanto este precepto constituye una proclamación del Estado de Derecho, sino también en la medida en que declara que la libertad es un valor superior del ordenamiento español”. Además, aparte de estas declaraciones genéricas, "la vigencia del principio de prohibición de exceso puede inducirse de una serie de concretos preceptos constitucionales", entre los que destacan los artículos 15, 17.2, 17.4 y 55.2. Vid. COBO DEL ROSAL, M./VIVES ANTÓN, T. S., Derecho Penal. Parte General, Tirant lo blanch, Valencia 1999, pág. 82.

El valor constitucional de dicho principio ha sido reconocido por la STC 62/1982, de 15 de octubre, aplicándolo, como indican los citados autores, 
sólo es respetuosa con este principio si tiene lugar en aras de la protección de las condiciones fundamentales de la vida en común y para evitar ataques especialmente graves contra ellas ${ }^{62}$, o, dicho con otras palabras, si está destinada a garantizar, como indica VIVES ANTÓN, el máximo de libertad posible:

"La libertad se concreta en una serie de bienes e intereses que representan las condiciones externas -materiales- de su ejercicio.

al problema de la limitación de los derechos fundamentales e infiriéndolo del artículo 10.2 de la Constitución en relación con los artículos 10.2 y 18 del Convenido de Roma. Otras sentencias del Tribunal Constitucional relevantes en este sentido son las siguientes: 65/1986, de 22 de mayo; 66/1985, de 23 de mayo; 160/1987, de 27 de octubre; 19/1988, de 16 de febrero; 150/1991, de 4 de julio; 85/1992, de 8 de junio; 111/1993, de 25 de marzo; $50 / 1995$, de 23 de febrero; 173/1995, de 21 de noviembre; y 55/1996, de 28 de marzo.

En esta última el Tribunal Constitucional (Fundamento Jurídico tercero) afirma que "el principio de proporcionalidad no constituye en nuestro ordenamiento constitucional un canon de constitucionalidad autónomo cuya alegación pueda producirse de forma aislada respecto de otros preceptos constitucionales. Es, si quiere decirse así, un principio que cabe inferir de determinados preceptos constitucionales -y en particular de los aquí invocados (v.g. arts. 1.1, 9.3 y 10.1)-y, como tal, opera esencialmente como un criterio de interpretación que permite enjuiciar las posibles vulneraciones de concretas normas constitucionales. Dicho con otras palabras, desde la perspectiva del control de constitucionalidad que nos es propio, no puede invocarse de forma autónoma y aislada el principio de proporcionalidad, ni cabe analizar en abstracto si una actuación de un poder público resulta desproporcionada o no. Si se aduce la existencia de desproporción, debe alegarse primero y enjuiciarse después en qué medida ésta afecta al contenido de los preceptos constitucionales invocados: sólo cuando la desproporción suponga vulneración de estos preceptos cabrá declarar la inconstitucionalidad".

En suma, y resumiendo los diversos pronunciamientos del Tribunal Constitucional en relación con el principio de proporcionalidad, éste se deriva, como señala AGUADO CORREA, T. (El principio de proporcionalidad en Derecho Penal, ob. cit., pág. 134), de los artículos 1.1, 9.3 y 10.1. "No se trata, como ocurre con el principio de legalidad, de un principio contemplado como un derecho fundamental, sino, tal y como ha expresado el Tribunal Constitucional, un principio reconocido implícitamente en tres preceptos constitucionales de gran relevancia".

62 Vid. SILVA SÁNCHEZ, J. M., Aproximación al Derecho Penal contemporáneo, ob. cit., pág. 267. 
Por lo que la idea del derecho como orden de coexistencia de las libertades comporta una opción acerca de la función primordial del derecho penal, que no puede ser otra que la de protección de ese conjunto de bienes e intereses reconocidos por el derecho como correlatos de la libertad.

De este modo, la esencia de la infracción del derecho -el injusto- aparece desde el plano constitucional caracterizado como ataque a la libertad ajena (a la coexistencia de libertades); y, a la vez, y precisamente por ello, como lesión o puesta en peligro de un bien jurídico.

La noción de bien jurídico cobra así la importancia que le corresponde, y aparece como un límite frente al legislador; mas como un límite derivado, no de simples exigencias doctrinales, sino precisamente de la Constitución" "63.

Introducida la exigencia de que la intervención penal obedezca, sin excepción, a necesidades de tutela de bienes jurídicos, el Derecho Penal aparecerá como "como guardián, protector y conservador de bienes e intereses constituidos, y no como un orden meramente imperativista, regulador de las voluntades individuales" ${ }^{\prime \prime}$.

El carácter conservador del Derecho Penal, en el que interpreta un importante papel el principio de previa distribución de bienes jurídicos, no impide, sin embargo, su adjetivación como progresista o conservador en el sentido político del término. "Ello sería rotundamente falso; es más, no resulta en absoluto descabellado afirmar que el carácter progresista o conservador de un Ordenamiento depende de su Derecho Penal" ${ }^{\prime}$.

63 Vid. VIVES ANTÓN, T. S., "Reforma política y Derecho Penal", en La libertad como pretexto, Valencia 1995, pág. 97

64 Vid. COBO DEL ROSAL, M./VIVES ANTÓN, T. S., Derecho Penal. Parte General -1999-, ob. cit., pág. 315.

65 Vid. CARBONELL MATEU, J. C., Derecho penal: concepto y principios constitucionales, Tirant lo blanch, Valencia 1999, pág. 34. En el mismo sentido, MUÑOZ CONDE, Francisco, Edmund Mezger y el Derecho Penal de su tiempo. Estudios sobre el Derecho penal en el Nacionalsocialismo, Tirant lo blanch, Valencia 2002, págs. 119 y 120: "el Derecho Penal vigente en 
Detrás del principio de exclusiva protección de bienes jurídicos, cuyo reconocimiento y fortaleza son característicos de una concepción liberal del Estado ${ }^{66}$, y de su Derecho Penal, inspirada en la nítida distinción entre Derecho y Moral ${ }^{67}$, está el convencimiento de que sólo las manifestaciones exteriorizadas de la voluntad son susceptibles de castigo y ello siempre que supongan, además, una ofensa para un bien jurídico ${ }^{68}$. Esta doble exteriorización, de voluntad, primero, y de ofensividad, segundo, constituye una garantía irrenunciable de la libertad del individuo frente a la potestad punitiva del Estado, impidiendo una invasión intolerable de aquélla.

Sometida la intervención del Derecho Penal a los límites incorporados por la necesidad de respetar un espacio mínimo de libertad individual, el castigo de meras actitudes interiores, conductas inocuas o simplemente inmorales deviene contrario a la Constitución ${ }^{69}$. Dicho de otro modo, el Derecho Penal ha de admitir como buenas todas las conductas, incluso las manifesta-

cada país en una época o momento histórico determinado, no es en absoluto neutro, sino quizás la parte más ideologizada de todo el Ordenamiento Jurídico, que, como la Historia y el Derecho comparado muestran, no sólo ha servido o sirve para proteger y garantizar derechos y libertades fundamentales, sino también para reprimirlas y violentarlas desde el propio Estado".

66 Vid., en este sentido, JESCHECK, H. H., Tratado de Derecho Penal. Parte General, Comares, Granada 2002, pág. 9.

67 Vid. COBO DEL ROSAL/VIVES ANTÓN, Derecho Penal. Parte General -1999-, ob. cit., pág. 315. Como afirma este segundo autor ("Reforma política y Derecho Penal", ob. cit., pág. 100), en un ordenamiento jurídico concebido como un orden de libertad la moral no puede ser objeto de protección penal, "porque se halla fundado sobre la idea de que, en el campo moral, el hombre es absolutamente autónomo, y se halla, en consecuencia, sometido exclusivamente a su propia legislación".

68 "Las perturbaciones sociales, no las morales, son las que el Derecho repri$m e$ ". GROIZARD y GÓMEZ DE LA SERNA, Alejandro, El Código Penal de 1870, t. I, Madrid 1923, pág. 98.

69 No olvidemos que el principio de protección de bienes jurídicos halla sus raíces en la propia Constitución y que, como indican COBO DEL ROSAL/ VIVES ANTÓN (Derecho Penal. Parte General -1999-, ob. cit., pág. 316), a partir de las SSTC 11/1981 y 62/1982 la protección de un bien jurídico ha de estimarse requisito indispensable de cualquier limitación de derechos constitucionales y, por lo tanto, de las injerencias de naturaleza penal. 
ciones de voluntad delictiva exteriorizadas, que no sean lesivas para los intereses ajenos ${ }^{70}$ : las conductas que no agreden, que no son trascendentes, en sentido negativo, para la libertad de los demás, han de ser irrelevantes"1. "Sólo un Derecho Penal que respete este principio es propio de un Estado democrático de Derecho" 7273.

Subrayada la orientación garantista del principio de exclusiva protección de bienes jurídicos, en virtud del cual la intervención penal sólo procederá si responde a la necesidad de tutelar un bien jurídico, es preciso destacar también su vocación preventiva, aparentemente contradictoria con la citada orientación garantista. En efecto, limitando la potestad de establecer delitos y, consecuentemente, prever penas, el principio de exclusiva protección de bienes jurídicos supone una opción a favor de la libertad y, por tanto, en contra del castigo; mas, al mismo tiempo, y en la medida en que conlleva el reconocimiento de la validez de la amenaza de pena ${ }^{74}$ como medio de tutela de bienes,

70 “Así como un mero pensamiento no puede constituir ninguna perturbación de la vida en común, tampoco puede serlo cualquier conducta que se mantenga en la esfera privada, en la medida en que la esfera privada no concurra con la de otra persona y deje entonces de ser privada. Lo que, junto con sus efectos, reside todavía en la esfera en la que un ciudadano puede legítimamente oponerse a controles públicos, desde la intimidad del cuerpo hasta los contactos sociales reservados, no puede ser preparación punible, tentativa o, mucho menos aún, consumación de un delito". Vid. JAKOBS, Gunther, "Criminalización en el estado previo a la lesión de un bien jurídico", en Estudios de Derecho Penal, Ediciones de la Universidad Autónoma de Madrid, 1997, págs. 298.

71 Vid. CARBONELL MATEU, Derecho penal: concepto y principios constitucionales -1999-, ob. cit., pág. 31.

72 Vid. CARBONELL MATEU, Derecho penal: concepto y principios constitucionales -1999-, ob. cit., pág. 31.

73 "Para fundamentar la conminación penal no basta la simple manifestación de voluntad antijurídica, como sostienen las teorias subjetivas, sino que es preciso que esa manifestación tenga lugar de tal modo que represente, a la vez, un peligro, siquiera sea abstracto, para el bien jurídico". Vid. COBO DEL ROSAL, M./VIVES ANTÓN, T. S., Derecho Penal. Parte General -1999-, ob. cit., pág. 713.

$74 \mathrm{Y}$, en su caso, imposición. 
la decisión de crear delitos, implicando, a su vez, una elección por la seguridad, puede merecer una valoración positiva. Con otras palabras, aunque, trazando las fronteras de la intervención punitiva, el principio de protección de bienes delimita un espacio de libertad, su aceptación como principio del Derecho Penal confiere a éste su específica, y exclusiva, función tutelar ${ }^{75}$.

Matizar la misión tutelar de bienes del Derecho Penal subrayando que su función es la exclusiva protección de bienes jurídicos no significa que este sea el único sector del Derecho que desempeña funciones de dicha naturaleza, pues éstas son comunes a otras disciplinas jurídicas, sino que esa es su única función: el Derecho Penal y, por tanto, cada uno de sus delitos, nace exclusivamente para proteger bienes jurídicos, aunque no sea esta una función exclusiva del Derecho Penal.

El principio de protección de bienes jurídicos, por todo ello, no limita, simplemente, la intervención penal, sino que, además, la fundamenta y promueve. Su utilidad como instrumento de tutela ${ }^{76}$ y la generalizada convicción de que el Derecho Penal es ${ }^{77}$ "una amarga necesidad en la comunidad de seres imperfectos que son los hombres", impulsan y justifican la creación de nuevos delitos, la extensión de las zonas de dominio penal, un proceso, en fin, que sólo será juzgado negativamente si no traduce sentidas necesidades de tutela.

75 Que la protección de bienes jurídicos es la función propia del Derecho Penal es, como indica ÁLVAREZ GARCÍA, J., (Introducción a la Teoría jurídica del delito, Tirant lo blanch, Valencia 1999, pág. 11), "una opinión más que consolidada en la doctrina y en la jurisprudencia, y sobre cuya base se ha construido todo el Derecho penal contemporáneo".

76 "El Derecho Penal es un instrumento cualificado de protección de bienes jurídicos especialmente importantes”. Vid. SILVA SÁNCHEZ, J., La expansión del Derecho Penal. Aspectos de la política criminal en las sociedades postindustriales, Civitas, Madrid 2001, pág. 25.

77 Como se afirmaba en el Proyecto Alternativo (Alternativ-Entwurf) de un nuevo Código Penal alemán, presentado en 1966 por un grupo de profesores en oposición al Proyecto gubernamental de 1962. 
Dichas necesidades pueden hallar su origen, como destaca SILVA SÁNCHEZ ${ }^{78}$, en la aparición de nuevos bienes jurídicos o en el aumento de valor experimentado por alguno de los que ya existían con anterioridad, circunstancia, ésta, que podría legitimar su tutela a través del Derecho Penal ${ }^{79}$. En cualquier caso, y con independencia ahora de las causas que generan las aludidas necesidades, parece existir "un espacio de «expansión razonable» del Derecho Penal"s0.

\subsection{El bien jurídico protegido por el delito de ocupación o mantenimiento del artículo 245.2.}

Los delitos de usurpación tipificados en el Capítulo V del Título XIII del Libro II del Código Penal constituyen, como hemos visto, y así lo subraya la ya diversas veces referida Sentencia núm. 800/2014 del Tribunal Supremo, una modalidad de delitos patrimoniales que tutelan específicamente los derechos reales sobre bienes inmuebles.

El delito previsto y penado en el artículo 245.2 tiene como función, en concreto, según dicha sentencia, proteger el patrimonio inmobiliario ${ }^{81}$ : como delito patrimonial, "la lesión

78 Vid. SILVA SÁNCHEZ, J., La expansión del Derecho Penal. Aspectos de la política criminal en las sociedades postindustriales, ob. cit., pág. 25.

79 Entre las diversas causas de la probable existencia de nuevos bienes jurídico-penales "cabe considerar la conformación o generalización de «nuevas realidades» que antes no existían -o no con la misma incidencia-", como "las instituciones económicas del crédito o de la inversión"; por otro lado, "debe aludirse al deterioro de "realidades tradicionalmente abundantes» $y$ que en nuestros dias empiezan a manifestarse como "bienes escasos», atribuyéndoseles ahora un valor que anteriormente no se les asignaba, al menos de modo expreso", constituyendo un ejemplo de ello "el medio ambiente"; en tercer lugar, "hay que contemplar el incremento esencial de valor que experimentan, como consecuencia del cambio social y cultural, ciertas realidades que siempre estuvieron ahi, sin que se reparara en las mismas", como, por ejemplo, "el patrimonio histórico-artístico". Vid. SILVA SÁNCHEZ, J., La expansión del Derecho Penal. Aspectos de la politica criminal en las sociedades postindustriales, ob. cit., pág. 25.

80 Vid. SILVA SÁNCHEZ, J., La expansión del Derecho Penal. Aspectos de la política criminal en las sociedades postindustriales, ob. cit., pág. 26.

81 Si así fuere, resultarían atípicas las ocupaciones de viviendas que no tuvieren la condición de inmueble. 
del bien jurídico requiere que se ocasione un perjuicio al titular del patrimonio afectado, que es el sujeto pasivo del delito".

Tomando como base esta idea, declara el Alto Tribunal que "la ocupación inmobiliaria tipificada penalmente es la que conlleva un riesgo relevante para la posesión del sujeto pasivo sobre el inmueble afectado, que es lo que dota de lesividad y significación típica a la conducta, por lo que las ocupaciones ocasionales o esporádicas, sin vocación de permanencia o de escasa intensidad, son ajenas al ámbito de aplicación del tipo".

En el caso sometido, vía recurso de casación, a su enjuiciamiento, analiza el Tribunal Supremo, en primer lugar, la alegación "de que los hechos no revisten la gravedad suficiente para fundamentar una condena por delito desde la perspectiva de la efectiva perturbación de la posesión del titular de la finca ocupada". "Considera la parte recurrente", sigue explicando el Tribunal Supremo, "que la exigencia de una gravedad o intensidad relevante en la ocupación constituye una consecuencia necesaria del carácter subsidiario de la norma penal. Y finalmente estima que en el caso actual la perturbación posesoria es ocasional, sin vocación de permanencia y de poca intensidad, por lo que debe considerarse atípica".

Aunque "la construcción jurídica en que se apoya esta alegación es correcta, en abstracto, según lo anteriormente expuesto", afirma el Alto Tribunal que "no resulta aplicable al caso enjuiciado. En efecto, esta argumentación resultaría aplicable si efectivamente nos encontrásemos ante una ocupación ocasional, esporádica, sin vocación de permanencia, como lo sería la que durase un breve periodo temporal, el necesario para obtener la repercusión pública de la reclamación de carácter social que fundamentaba la acción realizada. Pero lo cierto es que en el caso actual se superó muy ampliamente esta naturaleza de acto simbólico que la ocupación tenía inicialmente como protesta social, para convertirse en una ocupación que los propios ocupantes calificaban como permanente o indefinida, y que habría de durar hasta que consiguiesen sus reivindica- 
ciones, sin consideración alguna al perjuicio que determinaba para los usos ordinarios a los que su titular destinaba la finca, prolongándose la perturbación de forma desproporcionada durante dieciocho días".

Para estimar cometido un delito de ocupación del artículo 245.2 es preciso comprobar, en suma, que el bien protegido ha sido lesionado, es decir, que la posesión del inmueble, vivienda o edificio se ha visto afectada. Debe, dicho de otro modo, identificarse una perturbación efectiva del contenido de los derechos posesorios, es decir, de las facultades de uso y disfrute del inmueble e, incluso, de exclusión de terceros.

La ocupación de un inmueble en situación de abandono, sobre el cual, por tanto, su titular no ejerce actualmente, en ninguna medida, sus facultades de uso y disfrute, resultará atípica por falta de afección del bien jurídico protegido. Así, por ejemplo, será atípica la ocupación de un viejo edificio que carece de puertas y ventanas, invadido por plantas silvestres, no utilizado por su titular desde hace años, pero habitualmente empleado por adolescentes para reunirse. No se habría producido en tal caso una efectiva interferencia en el ejercicio actual o dinámico de los derechos posesorios del titular del edificio. La ocupación, dicho de otro modo, no habrá modificado dichos derechos. La conducta, por supuesto, es ilícita, pero penalmente irrelevante.

La identificación de la perturbación posesoria penalmente relevante exige demostrar, por así decirlo, que hay un antes y un después de la ocupación, que la situación del inmueble, edificio o vivienda se ha visto sensiblemente modificada. Si, por ejemplo, su titular ofrecía el bien en arrendamiento o tenía la intención de repararlo para utilizarlo directa o indirectamente o para introducirlo en el mercado inmobiliario, se habrá producido aquella efectiva perturbación posesoria.

Dicha perturbación posesoria penalmente relevante debe predicarse, por supuesto, de toda ocupación o mantenimiento, con independencia de que su objeto material sea un edificio, una vivienda o un inmueble que no sea ni lo primero ni lo segundo. 
No serán punibles, resumidamente, según indica MANGAS CAMPOS, "las conductas que se enumeran, sin ánimo de exhaustividad, a continuación:

- Las ocupaciones transitorias u ocasionales, sin ánimo de ejercer derechos posesorios, como pueden ser las meras entradas para dormir.

- Las ocupaciones que recaigan sobre inmuebles no susceptibles de establecer aquella relación reconocible, como ocurre respecto a los edificios abandonados y en estado de absoluta inhabitabilidad o ruina total.

- Casos en que la posesión se concede por el titular del bien, y a sea como consecuencia de un contrato ya sea por la concesión de un verdadero y propio precario, o en aquellos otros en que por efecto también de un contrato el que está poseyendo adquiere la obligación de entregar la posesión a la contraparte contractual" "82.

6.2.1. Ocupación y mantenimiento: diferencias. Ejercicio actual de los derechos posesorios cuando su titular exige el desalojo

El artículo 245.2, como hemos visto, distingue dos modalidades típicas: la ocupación sin autorización debida y el mantenimiento contra la voluntad de su titular. Esta diferenciación quizá deba tener repercusión en la consideración, o no, como delictiva, de una determinada conducta. Si un grupo de personas ocupan un edificio abandonado sin autorización debida, literalmente realizan el comportamiento típico, pero sin simultánea lesión del bien protegido. Advertido el titular del edificio de dicha situación, exige a los ocupantes que lo desalojen. Esta expresión de voluntad supone un ejercicio actual de sus derechos posesorios y el mantenimiento posterior, por tanto, su efectiva lesión. Ahora sí habrá un antes y un después de la ocupación; la situación sí habrá cambiado como consecuencia de la ocupación.

82 Vid. MANGAS CAMPOS, "La interpretación del artículo 245.2 del Código Penal y el activismo judicial", Diario La Ley, № 8672, Sección Doctrina, 28 de Diciembre de 2015, Ref. D-487, Editorial LA LEY. 
El mantenimiento contra la voluntad de su titular será posterior, por otra parte, como habíamos exigido, a una ilícita ocupación, si bien esta no realizaba, por ausencia de afección del bien jurídico, el tipo objetivo del artículo 245.2. ¿Debe considerarse penalmente típico dicho posterior mantenimiento contra la voluntad de su titular?

Como hemos explicado antes, el tenor literal del tipo no lo impide; además, como acabamos de destacar, la ocupación del inmueble, pese a no ser penalmente relevante, es, eso sí, ilícita, y la exigencia de desalojo de su titular supone un ejercicio actual de sus derechos posesorios con efectiva lesión de estos, si se produce el mantenimiento. La conclusión, parece evidente, debe ser afirmar la tipicidad de la conducta.

Queda perfectamente dibujado, así, el ámbito de aplicación de esta modalidad de usurpación subsidiaria de la ocupación: existirá delito de mantenimiento en un inmueble contra la voluntad de su titular si se ocupó con simultánea realización del tipo objetivo del artículo 245.2 pero sin dolo y aquel se produce una vez conocida la situación; también si tuvo lugar una penalmente atípica pero ilícita ocupación y el titular del inmueble exige el desalojo, suponiendo el mantenimiento subsiguiente una lesión efectiva de su ejercicio actual de los derechos posesorios.

\subsubsection{Hurto de uso y utilización indebida de bien inmueble}

Explicado todo ello debe ocuparnos, ahora, una nueva cuestión: ¿es necesario que la usurpación suponga la exclusión del ejercicio de los derechos posesorios del titular? No es difícil imaginar situaciones en las que la ocupación no impedirá dicho simultáneo ejercicio: si dos personas se instalan con su caravana en un rincón de un terreno de 40.000 metros cuadrados que el titular no utiliza (por ejemplo, por destinarlo a su cultivo), este podrá seguir paseando por la finca $\mathrm{y}$, en su caso, por ejemplo, cultivándola. Existirá, por tanto, en sentido literal, ocupación, si bien compatible con el uso de bien (con exclusión de aquel rincón) por parte de su titular. ¿Es típica la conducta? 
Literalmente, una vez más, no resulta difícil afirmar que sí. Ahora bien, el bien jurídico, ciertamente, sufrirá en menor medida que si la ocupación resulta incompatible con el uso actual del bien, con el ejercicio por parte de su titular de los derechos posesorios. ¿Es suficiente la afección de dicho bien para estimar cometido un delito del artículo 245, número 2 ?

La diferencia entre ocupación con o sin simultánea exclusión del ejercicio de los derechos posesorios del titular del inmueble recuerda en cierta medida la distinción entre el hurto de uso de vehículos de motor o ciclomotores y su indebida utilización.

Si quien ocupa el inmueble excluye totalmente el mentado ejercicio de los derechos posesorios del titular, se producirá una sustracción por parte del primero o, dicho de otra forma, tendrá lugar un hurto de uso del bien inmueble. Si no concurre aquella exclusión, el ocupante realizará una utilización sin la debida autorización del bien inmueble.

Uno, el hurto de uso del bien inmueble, y la otra, su utilización indebida, literalmente realizan el tipo penal y, además, lesionan el bien jurídico por él protegido, si bien, como decía, la segunda lo hace en menor medida.

Repetiré la pregunta: ¿es típica la segunda conducta? Quizá, atendida la menor afección del bien tutelado, quepa estimarla penalmente irrelevante, pero, una vez más, considero preciso diferenciar entre las dos modalidades de conducta tipificadas por el artículo 245.2. La ilícita ocupación inicial solo será delictiva si tiene lugar un hurto de uso del bien inmueble, esto es, su usurpación sin la debida autorización. Exigido el desalojo por parte del titular del inmueble, tendrá lugar un ejercicio actual de sus derechos posesorios, incrementando la lesión de estos el mantenimiento en el inmueble contra la voluntad del citado titular, que deberá considerarse penalmente típico. 


\section{Bibliografía}

AGUADO CORREA, T., El principio de proporcionalidad en Derecho Penal, Derecho Reunidas, Madrid 1999.

ÁlVAREZ GARCÍA, J., (Introducción a la Teoría jurídica del delito, Tirant lo blanch, Valencia 1999

ARAGONÉS SEIJO, S., "La ineficacia del delito de usurpación para el perjudicado: algunas ventajas del proceso civil", Revista Crítica de Derecho Inmobiliario, núm. 760, Marzo 2017.

BAUCELLS I LLADÓS, J., La ocupación de inmuebles en el Código Penal de 1995, Tirant lo Blanch, Valencia, 1995.

BAUCELLS I LLADÓS, J., La delincuencia por convicción, Tirant lo Blanch, Valencia, 2000.

BAUCELLS LLADÓS, J., "Comentario al art. 245 del Código Penal", en Comentarios al Código Penal. Parte Especial. Tomo I, directores Juan Córdoba Roda y Mercedes García Arán, Marcial Pons, Madrid 2004.

BOLEA BARDÓN, C., "Allanamiento de morada, domicilio de personas jurídicas y establecimientos abiertos al público (202-204)", Manual de derecho penal. Parte Especial. Doctrina y jurisprudencia con casos solucionados. Tomo $\underline{1}$, coord. por Juan Sebastián Vera Sánchez; Mirentxu Corcoy Bidasolo (dir.), 2015, Tirant lo blanch, Valencia 2015.

BORJA JIMÉNEZ, E., «El bien jurídico protegido en el delito de allanamiento de morada», en Estudios Jurídicos en memoria del Profesor Doctor Don José Casabó Ruiz, vol. $1^{\circ}$, Valencia 1997.

BORJA JIMÉNEZ, E., Derecho Penal. Parte Especial, $5^{\text {a }}$ edición revisada y actualizada a la Ley Orgánica 1/2015, coord. José Luis González Cussac, Tirant lo blanch, Valencia 2015.

CARBONELL MATEU, J. C., Derecho penal: concepto y principios constitucionales, Tirant lo blanch, Valencia 1999. 
CARUSO FONTÁN, V., "La protección penal del legítimo disfrute de la vivienda", en Análisis delas reformas penales. Presente y futuro, dir. Muñoz Conde, F., Tirant lo Blanch, Valencia, 2015.

COBO DEL ROSAL, M./VIVES ANTÓN, T. S., Derecho Penal. Parte General, Tirant lo blanch, Valencia 1999.

COBO DEL ROSAL, M., "La nueva concepción del delito de usurpación", en lawyerpress news, Madrid, 18 de FEBRERO de 2014.

http://www.lawyerpress.com/news/2014_02/delito de usurpaci\% $\mathrm{C} 3 \% \mathrm{~B} 3 \mathrm{n} . \mathrm{html}$

DE LA MATA BARRANCO, , "Detención policial por comisión de delitos leves", en Almacén de Derecho, Julio 27, 2015, http://almacendederecho.org/detencion-policialpor-comision-de-delitos-leves/;

FARALDO CABANA, Los delitos leves. Causas y consecuencias de la desaparición de las faltas, Tirant lo Blanch, Valencia 2016.

GARCÍA DE HERRERA FERNÁNDEZ, J., "Notas prácticas acerca del delito de usurpación de viviendas. Especialidades en los casos de viviendas de protección de titularidad pública", El consultor de los Ayuntamientos, núm. 1, quincena del 15 al 29 de enero de 2017, Wolters Kluwer.

GÓMEZ IBARGUREN, P., "El fenómeno ocupa desde la perspectiva del Derecho penal", Noticias Jurídicas, noviembre, 2007, edición digital.

GONZÁLEZ RUS, J.J., "Delitos contra el patrimonio y el orden socio-económico (I)", COBO del ROSAL, M. (coord.), Derecho penal español. Parte especial, Dykinson, Madrid, 2005.

GONZÁLEZ RUS, Juan José, "Secuelas «colaterales» no pretendidas de la LO 1/2015, de 30 de marzo, de reforma del Código Penal", Diario La Ley, No 8553, Sección Tribuna, 3 de Junio de 2015, Ref. D-222, Editorial LA LEY.

GONZÁLEZ CUSSAC, J.L./ORTS BERENGUER, E., "Usurpación", Compendio de derecho penal: Parte general y parte especial, Tirant lo Blanch, Valencia, 2004. 
GROIZARD y GÓMEZ DE LA SERNA, Alejandro, El Código Penal de 1870, t. I, Madrid 1923.

GUILLÉN ÁLVAREZ, I., "Estudio y análisis jurídico de la nueva Ley Orgánica 4/2015, de protección de la seguridad ciudadana", Diario La Ley, No 8633, Sección Doctrina, 27 de Octubre de 2015, Ref. D-396, Editorial LA LEY.

HERNÁNDEZ GARCÍA/RAMÍREZ ORTIZ, "Las consecuencias procesales de la reforma", en Comentario a la reforma penal de 2015, dir. Gonzalo Quintero Olivares, Thomson Reuters Aranzadi, Cizur Menor, 2015.

HERNÁNDEZ PLASENCIA, J. U., en DÍEZ RIPOLLÉS/ ROMEO CASABONA (Coords.), Comentarios al Código Penal, parte especial II, Valencia 2004.

HUERTA TOCILDO, S. Protección penal del patrimonio inmobiliario, Ed. Civitas, $1^{\text {a }}$ edición. Madrid, 1980.

IBARRA SÁNCHEZ, J.L., "La ocupación del inmueble no destinado a morada. El delito de usurpación del artículo 245.2 del Código Penal”, Diario La Ley, nº 7305, 2009.

IZQUIERDO TÉLLEZ, "Se puede detener por delito leve", en Diario La Ley, núm. 8582, Sección Tribuna, 14 de julio de 2015.

JAKOBS, Gunther, "Criminalización en el estado previo a la lesión de un bien jurídico", en Estudios de Derecho Penal, Ediciones de la Universidad Autónoma de Madrid, 1997.

JESCHECK, H. H., Tratado de Derecho Penal. Parte General, Comares, Granada 2002.

JIMÉNEZ PARÍS, J. M., Usurpación pacifica de bienes inmuebles, https://eprints.ucm.es/43556/1/T39000.pdf, Tesis doctoral, Universidad Complutense de Madrid, 2017.

JIMÉNEZ PARÍS, J. M., "Desahucio exprés contra la ocupación de viviendas", Diario La Ley, $\mathrm{N}^{\circ}$ 9262, Sección Doctrina, 19 de Septiembre de 2018, Editorial Wolters Kluwer.

JIMÉNEZ PARÍS, J. M., La ocupación de inmuebles en el Código penal español, Reus, Madrid 2018.

JIMÉNEZ SEGADO, C., “¿Es delictiva la ocupación pacífica y sin autorización de un inmueble, vivienda o edificio 
ajenos que no constituyan morada?", La Ley Penal, $\mathrm{N}^{\circ}$ 102, Sección Consulta de los suscriptores, Editorial LA LEY, LA LEY 577/2013.

JORGE BARREIRO, A., El allanamiento de morada, Tecnos, Madrid 1987.

JORGE BARREIRO, A., "El delito de allanamiento de morada en el Código Penal de 1995", en DÍEZ RIPOLLÉS, J. L. (coord.), La ciencia del derecho penal ante el nuevo siglo: Libro homenaje al profesor doctor don José Cerezo Mir, Tecnos, Madrid, 2002.

LARRAURI PIJOAN, E., "El allanamiento de morada y el derecho a la vivienda", en $C P C \mathrm{n}^{\circ} 23$ (1984).

LÓPEZ JARA, "El nuevo procedimiento civil para garantizar la posesión de viviendas frente a su ocupación ilegal", Actualidad Civil, N. ${ }^{\circ}$ 6, Junio 2018, Editorial WOLTERS KLUWER.

MAGRO SERVET, V., "Casuística sobre el concepto penal de domicilio en la diligencia de entrada y registro", en $L A$ $L E Y$, núm. 2, 11 de febrero de 2002.

MAGRO SERVET, V., "La criminalización de la no devolución posesoria por el arrendatario del inmueble en el impago de alquileres", Diario La Ley, No 6922, Sección Doctrina, 10 de Abril de 2008, Año XXIX, Ref. D-111, Editorial LA LEY.

MAGRO SERVET, "Ocupación ilegal de inmuebles: ¿delito del artículo 245.2 CP o precario?", La Ley Penal, N. ${ }^{\circ} 85$, Septiembre 2011, Editorial LA LEY.

MAGRO SERVET, V., "Soluciones ante la presencia de okupas, pisos patera y defraudación de fluido eléctrico en las comunidades de vecinos. ¿Cómo actuar ante alquileres irregulares u ocupación de viviendas y los enganches ilegales de luz a vecinos?", Diario La Ley, No 8225, Sección Tribuna, 9 de Enero de 2014, Año XXXV, Ref. D-8, Editorial LA LEY, Leynfor, 17 de Enero de 2014.

MAGRO SERVET, V., "El delito de usurpación de inmuebles del artículo 245.2 CP: ¿Vía penal o vía civil?”, La Ley 
Penal, N. ${ }^{\circ}$ 126, Mayo-Junio 2017, Editorial WOLTERS KLUWER.

MAGRO SERVET, "La inminente reforma civil y penal en materia de «okupación» de inmuebles", Diario La Ley, N. ${ }^{\circ}$ 9204, 24 de Mayo de 2018, Editorial WOLTERS KLUWER.

MAGRO SERVET, V., "Análisis de los títulos de oposición de los «okupas» ante demandas por la vía del art. 441.1 bis. $2^{\circ}$ LEC", Diario La Ley, № 9419, Sección Doctrina, 21 de Mayo de 2019.

MANGAS CAMPOS, A., "La interpretación del artículo 245.2 del Código Penal y el activismo judicial", Diario La Ley, No 8672, Sección Doctrina, 28 de Diciembre de 2015, Ref. D-487, Editorial LA LEY.

MANZANARES SAMANIEGO, J.L., "La llamada usurpación pacífica: Artículo 245.2 del Código Penal”, en Actualidad Penal 1997, pp. 901-915.

MARTÍ MARTÍ, J., "Desahucio por precario contra el movimiento «ocupa»", Diario LA LEY, Año XXVII. Número 6446, miércoles, 22 de marzo de 2006.

MARTÍ MARTÍ, J., "Los colectivos "okupas" y la respuesta del derecho penal", Diario LA LEY, núm. 7556, Sección Tribuna, de 27 de enero de 2011.

MARTÍ MARTÍ, J., "La protección del derecho penal frente a la ocupación de los bienes inmuebles por colectivos «ocupas»", Diario La Ley, No 7999, Sección Tribuna, 11 Ene. 2013, Editorial LA LEY.

MATÍA PORTILLA, F. J., "El allanamiento de morada, domicilio de personas jurídicas y establecimientos abiertos al público", en GÓMEZ TOMILLO, M. (dir.), Comentarios al Código Penal, Lex Nova, Valladolid, 2010.

MESTRE DELGADO, E., “La usurpación”, en LAMARCA PÉREZ, C (coord.), Delitos y faltas. La parte especial del derecho penal, Colex, 2012, $5^{\text {a }}$ ed.

MIR PUIG, S., Derecho Penal. Parte General, Reppertor, Barcelona 2002. 
MIRAPEIX LACASA, N., La usurpación pacifica de inmue$\underline{\text { bles, }}$ Tesis doctoral dirigida por David Felip i Saborit (codir. tes.), Mariona Llobet Anglí (codir. tes.). Universitat Pompeu Fabra (2016).

https://www.tesisenred.net/bitstream/handle $/ 10803 / 385917 / \mathrm{tnml} . p d f$ ? sequence $=1 \&$ isAllowed $=y$

MIRAPEIX LACASA, "Las ocupaciones de inmuebles por motivos de necesidad", Revista electrónica de ciencia penal y criminología, 20-22, 2018.

MORALES PRATS, F., "Comentario al art. 202 del Código Penal", en Comentarios al Código Penal español. Tomo I (Artículos 1 a 233), $7^{\text {a }}$ edición, Aranzadi, Pamplona 2016, ebook.

MUÑOZ CONDE, F./GARCÍA ARÁN, M., Derecho Penal. Parte General, Tirant lo blanch, Valencia 2002.

MUÑOZ CONDE, Francisco, Edmund Mezger y el Derecho Penal de su tiempo. Estudios sobre el Derecho penal en el Nacionalsocialismo, Tirant lo blanch, Valencia 2002.

MUÑOZ CONDE, F., Derecho Penal. Parte Especial, $21^{\text {a }}$ edición, revisada y puesta al día con la colaboración de Carmen López Pelegrín, Tirant lo blanch, Valencia 2017.

NOGUEIRAGANDÁSEGUI, S., Los delitos de usurpación de inmuebles en el Código Penal de 1995, Universidad de Santiago de Compostela. Facultad de Derecho, Santiago de Compostela, 1985.

PÉREZ DAUDÍ, V./ SÁNCHEZ GARCÍA, J., "La protección del propietario frente a los actos de ocupación ilegal de un bien inmueble", Diario La Ley, No 9008 , Sección Documento on-line, 26 de Junio de 2017, Editorial Wolters Kluwer.

RAMON RIBAS, E, "Interpretación extensiva y analogía”, Revista de Derecho Penal y Criminología, UNED, 3.a Época, núm. 12.

REBOLLO VARGAS, R., "Comentario al art. 202 del Código Penal”, en Comentarios al Código Penal. Parte Especial. Tomo I, directores Juan Córdoba Roda y Mercedes García Arán, Marcial Pons, Madrid 2004. 
REBOLlO VARGAS, R., "Comentario al art. 203 del Código Penal”, en Comentarios al Código Penal. Parte Especial. Tomo I, directores Juan Córdoba Roda y Mercedes García Arán, Marcial Pons, Madrid 2004.

ROCA AGAPITO, L., "Usurpación, alteración de lindes y distracción de aguas", Derecho Penal Español. Parte Especial (II), Álvarez García, F.J., director, Manjón-Cabeza Olmeda, A.,y Ventura Püschel, A., coord., Tirant lo Blanch, Valencia, 2011.

ROXIN, Derecho Penal. Parte General, Tomo I, Civitas, Madrid 1997.

RUIZ BLAY, G., "La ineficacia práctica del artículo 245 del Código Penal para obtener el desalojo de un inmueble usurpado", Diario La Ley, No 8429, Sección Dossier, 26 de Noviembre de 2014, Año XXXV, Editorial LA LeY.

SANZ MORÁN, A., El allanamiento de morada, domicilio de personas jurídicas y establecimientos abiertos al público, Tirant lo blanch, Valencia 2006.

SCHUMANN BARRAGÁN, G., "El proceso de tutela sumaria de la posesión por ocupación ilegal de viviendas introducido por la Ley $5 / 2018$. Su naturaleza jurídica y algunas implicaciones prácticas", Diario La Ley, N. ${ }^{\circ}$ 9264, 21 de Septiembre de 2018, Editorial WOLTERS KLUWER.

SILVA SÁNCHEZ, J. M., Aproximación al Derecho Penal contemporáneo, J.M. Bosch, Barcelona 1992.

SILVA SÁNCHEZ, La expansión del Derecho Penal. Aspectos de la politica criminal en las sociedades postindustriales, Civitas, Madrid 2001

SUÁREZ MONTES, R. F., "El delito de allanamiento de morada", separata de la Revista general de legislación y jurisprudencia, diciembre de 1968.

VÁZQUEZ PÉREZ, A. J., "El delito de usurpación: actuación policial ante una ocupación inminente", Ciencia policial: revista del Instituto de Estudios de Policía, núm. 131 (Julio/Agosto), 2015. 
VIVES ANTÓN, T. S., "Reforma política y Derecho Penal”, en La libertad como pretexto, Valencia 1995.

IVES ANTÓN, T. S./GONZÁLEZ CUSSAC, J. L, "Título XIII. Capítulo V", Comentarios al Código Penal de 1995, vol. II -arts. 234 a Disposiciones finales-, coord. Tomás Samuel Vives Antón, Tirant lo blanc, Valencia 1996. 